\title{
Asháninka medicinal plants: a case study from the native community of Bajo Quimiriki, Junín, Peru
}

Gaia Luziatelli $i^{*}$, Marten Sørensen ${ }^{1}$, Ida Theilade ${ }^{2}$, Per Mølgaard ${ }^{3}$

\begin{abstract}
Background: The Asháninka Native Community Bajo Quimiriki, District Pichanaki, Junín, Peru, is located only 4 km from a larger urban area and is dissected by a major road. Therefore the loss of traditional knowledge is a main concern of the local headman and inhabitants. The present study assesses the state of traditional medicinal plant knowledge in the community and compares the local pharmacopoeia with the one from a related ethnic group.

Methods: Fieldwork was conducted between July and September 2007. Data were collected through semistructured interviews, collection of medicinal plants in the homegardens, forest walks, a walk along the river banks, participant observation, informal conversation, cross check through voucher specimens and a focus group interview with children.

Results: Four-hundred and two medicinal plants, mainly herbs, were indicated by the informants. The most important families in terms of taxa were Asteraceae, Araceae, Rubiaceae, Euphorbiaceae, Solanaceae and Piperaceae. Eighty-four percent of the medicinal plants were wild and $63 \%$ were collected from the forest. Exotics accounted to only $2 \%$ of the medicinal plants. Problems related to the dermal system, digestive system, and cultural belief system represented $57 \%$ of all the medicinal applications. Some traditional healers received nonindigenous customers, using their knowledge as a source of income. Age and gender were significantly correlated to medicinal plant knowledge. Children knew the medicinal plants almost exclusively by their Spanish names. Sixteen percent of the medicinal plants found in this community were also reported among the Yanesha of the Pasco Region.

Conclusions: Despite the vicinity to a city, knowledge on medicinal plants and cultural beliefs are still abundant in this Asháninka Native Community and the medicinal plants are still available in the surroundings. Nevertheless, the use of Spanish names for the medicinal plants and the shift of healing practices towards a source of income with mainly non-indigenous customers, are signs of acculturation. Future studies on quantification of the use of medicinal plants, dynamics of transmission of ethno-medicinal knowledge to the young generations and comparison with available pharmacological data on the most promising medicinal plants are suggested.
\end{abstract}

\section{Background}

Peru is one of the twelve most biodiversity rich, or 'mega-diverse', countries of the world. Its combination of latitude and topography creates numerous ecosystems which are home to an extraordinarily rich flora and fauna. At least 25,000 species of plants, of which 5,354 are endemic, are hosted in its numerous ecosystems [1].

\footnotetext{
* Correspondence: gaia.luziatelli@gmail.com

'Department of Agriculture and Ecology, University of Copenhagen,

Rolighedsvej 21, DK-1958 Frederiksberg C, Denmark

Full list of author information is available at the end of the article
}

The country is also highly diverse in cultures represented by its many ethnic groups: according to the last census from 2007 the indigenous population of the Peruvian Amazon consists of approximately 333,000 individuals, belonging to 59 ethnic groups and 15 linguistic families. The largest ethnic group is the Asháninka with a population of almost 90,000 which represents $26 \%$ of the indigenous population recorded in the Peruvian Amazon [2].

Medicinal plants constitute an important resource to indigenous people, who often lack access to

\section{() Biomed Central}


conventional health care systems either due to isolation or to economy. This is a common condition in developing countries: e.g. in some African and Asian countries, $80 \%$ of the population depend on traditional medicine for primary health care [3], while according to WHO Regional Office for the Americas 40\% of the Colombian population and $71 \%$ of the Chilean population have used Traditional Medicine.

The Asháninka language belongs to the Arawak linguistic group and has affinities with the Piro, the Matsigenka and Yanesha languages in the Peruvian Amazon $[4,5]$. The Asháninka live in the foothills of the Andean region in the central part of Peru also known as 'Selva Alta' or 'Ceja de Selva', in the valleys of the Apurímac, Ene, Tambo, Satipo, Perené, Pichis and Pachitea rivers $[4,5]$. Literature on the Asháninka ethnic group has been produced mainly in the form of ethnographic studies $[4,6]$, while ethnobotanical studies are scarce. Existing ethnobotanical studies have so far been concentrated either in the Peruvian Amazons or 'Selva Baja' in the Departments of Loreto, Ucayali and Madre de Dios [7-24] or in the Peruvian Andes [25-27]. One of the few ethnobotanical studies specific to the Asháninka of the Peruvian Selva Central was published 20 years ago reported 96 species of medicinal plants indicated by 4 informants in 5 indigenous communities [5]. Keplinger et al. [28] present a brief description of the Asháninka medical system before focusing on the ethnomedicinal uses and pharmacological results of Uncaria tomentosa (Willd.) DC.,'uña de gato' (cat's claw) which is widely known and used by the Asháninka.

A more recent study conducted in four Asháninka communities, of which three in the Ucayali Department of Peru and one in the Brazilian state of Acre, reported interesting results on the structure, transmission and transformation of environmental knowledge in these communities [22,29]. Lenaerts [30] describes the ethnomedicine and in particular the relation between body and environment and inter-ethnic borrowing by the Ashéninka of the Ucayali and Ashéninka del Gran Pajonal, who are related to the Asháninka. However, this study does not include any details regarding plant identity with the stated purpose of protecting the indigenous intellectual property rights. Bletter [23] has proposed a new quantitative theoretical framework for discovering plant-derived medicines based on the hypothesis that "closely related plants used to treat closely related diseases in distantly related cultures have a higher probability of being effective". He compared the families and genera of the medicinal plants used by the Asháninka of Peru and the Malinké of Mali against eight diseases and found a significant similarity between the two medicinal floras, thought only if the diseases were grouped into the categories of parasitic and autoimmune diseases.
Sosnowska and Balslev [31] recently published a comprehensive review of the American palms used in local traditional medicine, based on literature from the last 25 years, which included also data on the Asháninka of Peru.

The Native Community of Bajo Quimiriki is located at the banks of the Perené River in the Peruvian Department of Junín. Here the majority of the population relies exclusively on medicinal plants for self-medication. This is due to the free availability of the resource, cultural traditions and cost of hospital treatments in the nearby town of Pichanaki. The proximity to Pichanaki does constitute a threat for the future survival of the indigenous knowledge and practicesas the younger generations are more and more assimilated by the dominant society. The children of the community spend most of the day at school, where they are taught in Spanish. This decreases their chances to learn about the uses of the medicinal plants from the older people. Several $[18,32,33]$ studies demonstrate that medicinal plants lore is particularly vulnerable to acculturation and the ethnocultural erosion due to globalization is discussed in numerous published ethnobotanical studies $[25,27]$.

The aim of the study was to document the medicinal tradition, thus contributing to an increased understanding of the distribution of knowledge among the community inhabitants, and to record the practices related to medicinal plant preparation and administration. Medicinal plant habitats and the frequency and use of cultivated and exotic plants were also investigated.

\section{Methods}

\section{Study area}

Bajo Quimiriki is located in the District of Pichanaki, Province Chanchamayo, Department Junín, at the oriental foothills of the Andes, with coordinates $10^{\circ} 56^{\prime} \mathrm{S}$ and $74^{\circ}$ $51^{\prime} \mathrm{W}$ (Figure 1). The distance to the neighbouring town Pichanaki is $4 \mathrm{~km}$, along the paved road that follows the river Perené connecting Pichanaki to the city of Satipo. The community covers an area of 268 ha and the altitude varies from $400 \mathrm{~m}$ a.s.l. along the basin of the Perené river to $900 \mathrm{~m}$ in the forest covered hills. However, most households are located along the Marginal Road at approximately $515 \mathrm{~m}$ a.s.l. The climate corresponds to the tropical-humid forest according to Holdridge's classification [34]. The mean annual precipitation is $1500 \mathrm{~mm}$, with main rainfall in January - March, whilst the driest months are June and July. The temperature during the year varies between $22^{\circ}$ and $26^{\circ} \mathrm{C}$ [35].

The population of Bajo Quimiriki includes 37 indigenous households and 6 households of colonos (non-indigenous Peruvians who migrated in the area in search for land to cultivate and/or better opportunities). The hutlike houses are close to each other, usually with people 


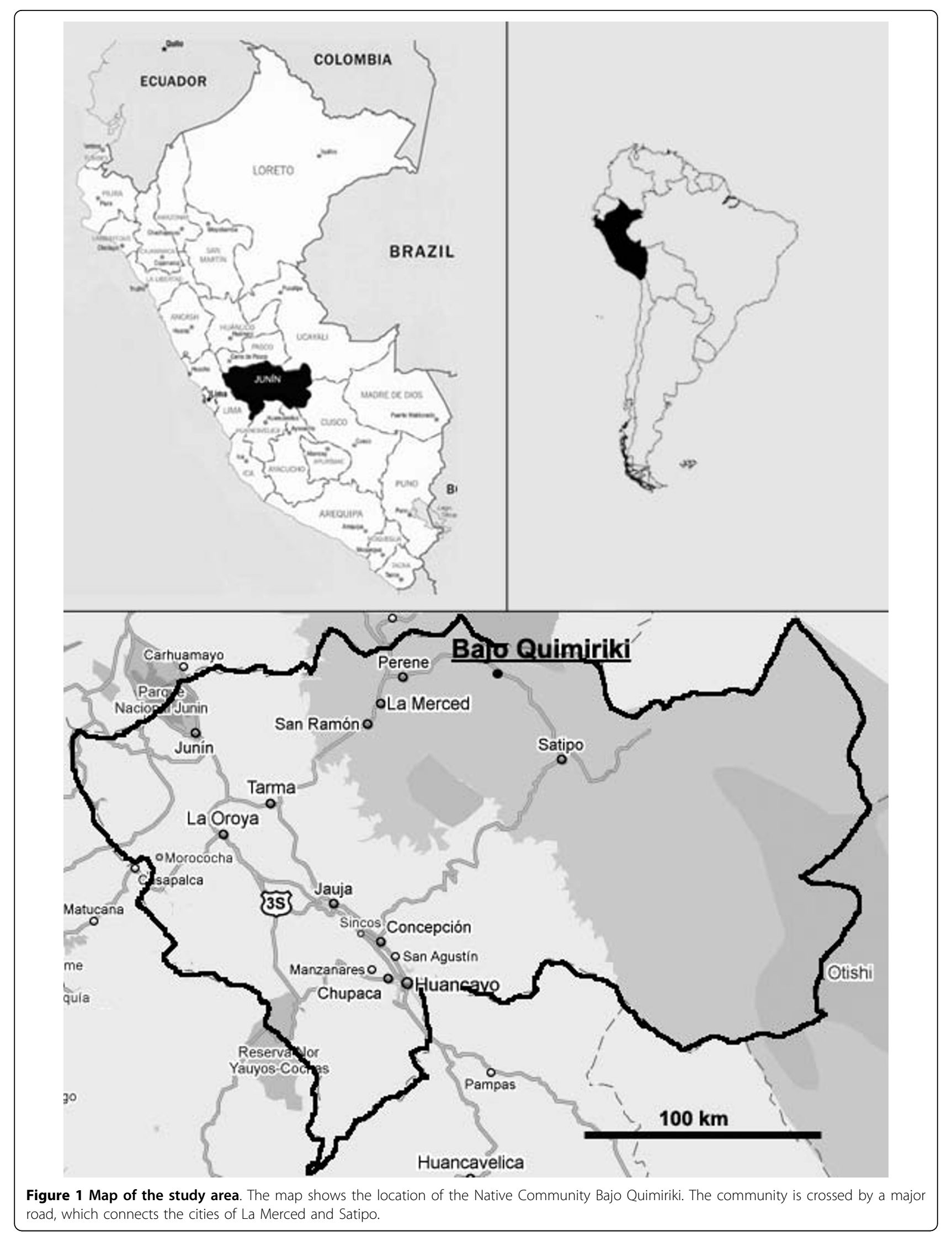


belonging to the same family living in proximity. They have one or two levels built with wooden support poles, cane walls and palm frond thatching. Every household has a piece of land for cultivation called 'chacra', the extent of which varies from 2 to 6 ha. In the past the main cultivated crop was yuca (Manihot esculenta Crantz), a staple food consumed roasted or used to produce 'masato', a fermented alcoholic drink. Other popular plants were achiote (Bixa orellana L.) used to paint bodies and arrows, platano (Musa paradisiaca L.), pituca (Xanthosoma sagittifolium Schott.), various types of beans and citrics. Nowadays, the need for cash has led to an intensification of the work in the chacra, where cash crops such as cacao (Theobroma cacao L.) and coffee (Coffea sp.) have been introduced, while the cultivation of achiote and bananas (Musa sp.) has been intensified to be sold in the market. Due to the need for cash, the men occasionally work the agricultural land of colonos as day labourers, while the women spend more time tending the chacra than before. Hence, they give less priority to traditional crafts like handweaving of the traditional tunic called 'cushma'.

\section{Methods of collection of ethnobotanical information}

The fieldwork was carried out during the period JulySeptember 2007.

In the course of two community meetings the people of the community agreed on the subject of the study, on the methods to be used and on eventual economic compensations.

Data were collected through household interviews, collection of medicinal plants in the homegardens, forest walks, a walk along the river banks, participant observation, informal conversation, cross check through voucher specimens and a focus group interview with children.

The informants for the forest walk were selected either because they were indicated by the deputy-headman as most knowledgeable on medicinal plants (after the 'specialists' who could not or did not want to participate) or in a couple of cases because they declared to make use of medicinal plants and agreed to participate in the event.

We attempted as far as possible to have an equal number of female and male informants, having for example six men and six women both in the forest walks and in the cross check with voucher specimens, but this was not possible for the households interviews because men were difficult to find at home. The walk on the river bank was done with three women indicated by the deputy-headman.

We agreed on a compensation corresponding to a daily salary of an agricultural worker in the area for the participants to the forest walks, which took a whole day.

\section{Household interviews}

Interviews were carried out in sixteen of a total of thirty-seven indigenous households (43\%). The informants were eleven women and five men. The households were chosen randomly. Semi-structured interviews were applied in order to present some important questions to all the households while remaining flexible as suggested by Cotton [36]. During the interviews the respondent's name, age, profession, place of birth, number of years spent in the community were recorded. Successively the respondents were asked who they believed were the most knowledgeable persons on medicinal plants in the household and in the community. The informants were also asked who they relied on in case of illness, e.g. self-medication, a healing specialist in the community, the doctor from nearby town, or others. Diseases that had occurred in the specific household were described, including information on causes, symptoms and their respective cure. Any herbal medicinal remedy stored in the house was recorded and its application described by the informant.

\section{Collection of medicinal plants in the homegardens}

A walk through the homegarden followed the household interview. The informants were asked to describe the medicinal application and preparation of any medicinal plant cultivated. Information was collected also on plants that were not actively cultivated but grew spontaneously in the proximity of the house and were indicated as medicinal.

\section{Forest walks}

In our study, differently from others [18,30,37-39] the ethnobotanical information on forest plants were collected in a no-random way, using forest walks rather than transects or quadrants with pre-selected species with DBH superior to $2.5,5$ or $10 \mathrm{~cm}$. We chose to apply this method as we did not have parcels with already identified species in proximity of the community and we did not want to limit our study to trees and lianas with diameter at breast height $(\mathrm{DBH})$ superior to $2.5,5$ or $10 \mathrm{~cm}$ as reported in numerous studies $[18,30,37-39]$ because we knew that medicinal plants are often herbs. A path in the community forest reserve was established with the help of three men recommended by the deputy headman as knowledgeable on the forest and medicinal plants. Medicinal plants identified by the informants were marked. Successively the forest route was walked with twelve informants, six men and six women of different ages. Each informant was guided through the route on a separate day. Interviews were made at each marked plant. The informant would be asked whether he/she knew the plant, and if yes, the name would be recorded in both in Asháninka and Spanish. The medicinal use, plant parts used and preparation were also recorded. In addition to the marked 
plants, all informants recognised a number of additional medicinal plants on the track: these were also collected. The performances of men and women were compared by summing up for each gender the number of events in which a medicinal application and preparation for one plant was described on the track (if an informant reported more than one use for the same plant it counts as one record).

\section{Walks on the river banks}

Some informants indicated that a number of medicinal plants were collected along the banks of the Perené River, where some of the community members had their chacra. A one day trip with three women from the village was organized to collect the medicinal plants of that area as well as information on uses and preparation. The women who participated in this collection were aged 25, 35 and 36 and they all had children.

\section{Cross check of information on 80 selected medicinal plants}

The study focused on the most well-known plants in the community based on the assumption that best known plants are more likely to contain active compounds with ability to cure particular diseases. Hence, a subset of plants recognised by more than one informant was selected for further analysis. Twenty of the pre-marked plant species recognised as medicinal by at least six out of twelve informants were selected from the forest walk. An additional twenty not pre-marked species, identified in the forest by more than one informant, were selected. The same method was used for twenty plants collected in the homegardens. Twenty out of twenty-three plants collected at the river were chosen eliminating those that had already been collected elsewhere. These eighty plants were shown in the form of herbarium specimens to six women and six men that had not participated in the forest walks, in order to perform a cross check of the ethnobotanical information.

\section{Focus group interview with children}

A focus group interview was conducted with the children of the $5^{\text {th }}$ and $6^{\text {th }}$ grade of elementary school to discuss their interest in and knowledge of medicinal plants. The interview was undertaken during a school hour. The class was composed of 17 children, 9 girls and 8 boys. The children were asked to list the medicinal plants they knew by heart and their uses and preparation. The answers were given collectively. During this exercise no voucher specimens were collected and the plants were identified by the vernacular names provided by the children.

\section{Preparation and identification of the voucher specimens}

The plant material was pressed and dried in the field. One set of the collected plants was deposited in the herbarium USM in Peru and a second set of plants was deposited in the herbarium CP in Denmark. The plants were partly identified in the herbarium USM with the help of local specialists and students (see Acknowledgments) and partly in Denmark with the help of various floras [40-44], books dealing with the medicinal flora of Peru and South America [1,45-53] and digital herbaria $[54,55]$. These sources were also used to determine the taxa origin. All the collection numbers and author names are reported in Additional file 1 under the scientific name of the plant. The author's names follow the standard form by Brummitt and Powell [56].

\section{Results}

Medicinal plants - diversity, life form and habitat

A total number of 402 taxa were indicated as having medicinal properties by the informants when applying the different ethnobotanical methods. The plants have been identified to the following different taxonomic hierarchic level: species (208 plants), genus (93 plants), family (54 plants), not identified (47 plants) (See Additional file 1). The taxa identified to family level (355 plants), belong to 72 distinct families. The six most important families in terms of number of taxa were Asteraceae, Araceae, Rubiaceae, Euphorbiaceae, Solanaceae and Piperaceae (Table 1). The plants indicated as medicinal were mostly herbs, but the local inhabitants used also shrubs, trees, vines, epiphytes, lianas and ferns (Table 2).

The majority of the medicinal plants were found in the forest $(63 \%)$, followed by the homegardens $(31 \%)$ and the river banks (6\%). Of the reported taxa $84 \%$ were wild and only $16 \%$ were cultivated (Figure 2 ).

Of the 301 plants identified to species or genus, only 5 species were exotics (2\%). They were: Artocarpus altilis (Parkinson) Fosberg, Moraceae; Aloe vera (L.) Burm. f., Asphodelaceae; Plantago major L., Plantaginaceae; Cymbopogon citratus (DC. ex Nees), Cyperaceae; Ocimum basilicum L., Lamiaceae [1,45,54,55,57-59].

\section{Plant parts used, ways of preparation and administration} Leaves were the most commonly used plant parts followed by roots, stem, bark, latex, fruit, caudex and rarely mentioned organs i.e. twigs, sap, seeds, tuberous rhizome, aerial roots (Table 3 ). The species were prepared mainly via decoction (56\%) or used fresh (22\%) (Table 4) while the most common way of administration was external (53\%), followed by oral administration (45\%) and application of drops in the eyes (3\%). During the households interviews we registered a preserved remedy only in 1 household out of 16 . This was an alcohol extract of Uña de gato (Uncaria guianensis (Aubl.) J. F. Gmel. or Uncaria tomentosa (Willd.) DC., Rubiaceae). None of the informants had western medicines at home.

\section{Ailments treated}

The 402 medicinal plants were used to cure in total 155 different ailments and diseases (Table 5). Problems 
Table 1 List of most important plant families in terms of species used as medicinal plants (families with at least three taxa)

\begin{tabular}{|c|c|c|c|}
\hline Family & No. of taxa & No. of vouchers & $\%^{*}$ \\
\hline Asteraceae & 31 & 44 & 12.4 \\
\hline Araceae & 17 & 29 & 8.2 \\
\hline Rubiaceae & 15 & 21 & 5.9 \\
\hline Euphorbiaceae & 15 & 17 & 4.8 \\
\hline Solanaceae & 13 & 17 & 4.8 \\
\hline Piperaceae & 13 & 18 & 5.1 \\
\hline Verbenaceae & 10 & 12 & 3.4 \\
\hline Fabaceae & 9 & 10 & 2.8 \\
\hline Cyperaceae & 9 & 9 & 2.5 \\
\hline Poaceae & 8 & 11 & 3.1 \\
\hline Malvaceae & 7 & 9 & 2.5 \\
\hline Commelinaceae & 7 & 7 & 2.0 \\
\hline Urticaceae & 6 & 8 & 2.3 \\
\hline Arecaceae & 6 & 7 & 2.0 \\
\hline Acanthaceae & 6 & 8 & 2.3 \\
\hline Bignoniaceae & 5 & 5 & 1.4 \\
\hline Apocynaceae & 5 & 7 & 2.0 \\
\hline Zingiberaceae & 4 & 4 & 1.1 \\
\hline Melastomataceae & 4 & 4 & 1.1 \\
\hline Gesneriaceae & 4 & 4 & 1.1 \\
\hline Tiliaceae & 3 & 3 & 0.8 \\
\hline Phytolaccaceae & 3 & 4 & 1.1 \\
\hline Moraceae & 3 & 3 & 0.8 \\
\hline Menispermaceae & 3 & 6 & 1.7 \\
\hline Maranthaceae & 3 & 3 & 0.8 \\
\hline Costaceae & 3 & 3 & 0.8 \\
\hline Clusiaceae & 3 & 3 & 0.8 \\
\hline
\end{tabular}

* The percentage is calculated on the 355 herbarium samples that have been identified.

related to the dermal system, digestive system and cultural belief system were among the most frequent ailments treated with the medicinal plants, representing $57 \%$ of all the medicinal applications (Figure 3).

During the household interviews, the diseases most frequently reported as having occurred in the families were (in decreasing order): 'mal aire', malaria, diarrhoea,

\section{Table 2 Life form}

\begin{tabular}{lcc}
\hline Life form & No. of taxa & $\%$ \\
\hline Herb & 209 & 65 \\
Shrub & 45 & 14 \\
Tree & 35 & 11 \\
Liana & 10 & 3 \\
Small tree & 7 & 2 \\
Vine & 7 & 2 \\
Epiphyte & 6 & 2 \\
Arborescent fern & 1 & 0.3 \\
\hline
\end{tabular}

'chacho', headache and intestinal parasites (Table 6). Mal aire, a condition provoked by the accidental encounter with a spirit or by a cold wind, was cured in $88 \%$ of the cases with external treatments, either washing the body with a plant decoction or with a steam bath. Malaria was commonly referred to as 'paludismo' by the inhabitants of the community; its symptoms were described as high fever, tremors, headache, pallor, absence of appetite. All the informants indicated the cause as the bite of infected mosquitoes. The plants indicated to cure malaria were often called 'kepishiri' which means 'bitter' or 'shawetashi' or 'shawetapini' from the word 'shaweta' which is a local word for 'butterfly', probably locally related with bitterness. All the remedies against malaria were taken orally. Diarrhoea was very frequent and the informants attributed its cause to the excessive consumption of fruits or the mixing of sour and sweet food. Eighty-nine percent of the remedies against diarrhoea were taken orally. 'Chacho' was considered a dangerous disease that occurred quite often and frequently required the intervention of the 'curandero' or the shaman. The local inhabitants recognised two forms of chacho: 'chacho de cerro' and 'chacho de agua'. The first occurred when the forest of the hills did not permit trespassing, or by falling asleep on a special rock in the forest. Contrastingly the second was provoked by the malevolent influence of spirits which resided in the water, usually in the river. The symptoms were fever, vomit, headache and body pain. It was cured in $77 \%$ of the cases by washing with an herbal decoction. Headache was a common ailment; it was treated in $47 \%$ of the reports by pouring in the eye a drop of latex or an extract of the leaves, stem or roots of the medicinal plant. The other ways of administration against headache were washing the body in plant decoction (28\%), oral administration (20\%) and steam bath (5\%). The cause of intestinal parasites was recognized as associated with consuming non-washed fruit and drinking non-boiled water. Intestinal parasites affected numerous adults and children. Ninety-four percent of the remedies were administered orally and six percent externally. One informant reported that the latex of Artocarpus altilis (Moraceae) should be applied on the belly bottom.

\section{Plants used against Leishmaniasis}

Leishmaniasis, an endoparasitic disease whose symptoms are skin ulcers, was locally known as 'uta' and the inhabitants distinguished two forms of it: 'uta seca' (dry uta) and 'uta de agua' (watery uta). Eleven species were reported against this disease (Table 7).

\section{Plants of cultural and social use}

A special group of plants were the so called 'pinitsi' and 'ivenki': these seemed to be the most traditional and 


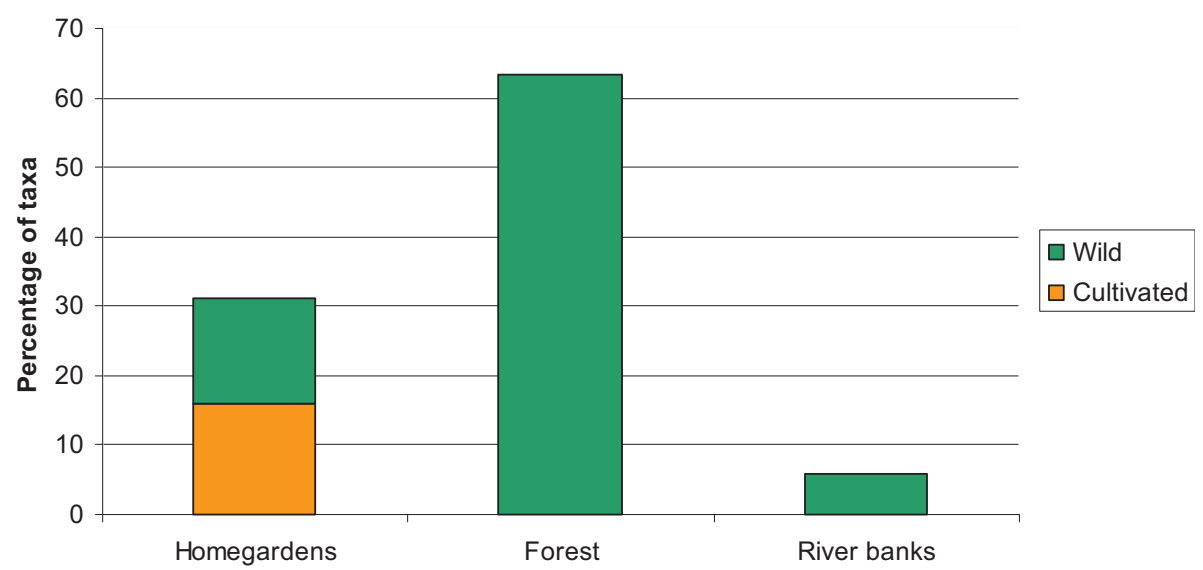

Figure 2 Medicinal plants habitats. Distribution to habitat of the 402 medicinal plants. A total of $63 \%$ of the species grow in the forest, $15 \%$ in the homegardens and 6\% on the river banks. Eight taxa grow both in the homegardens and in the forest, two grow both in the homegardens and on the river banks and one grows in all the three habitats. Eighty-one percent of the species is wild and 16\% cultivated.

sometimes secret plants and were always planted near the house. The pinitsi were small herbs of which unfortunately none could be identified either because their owners did not allow their collection or because they asked that their identity and use would not be revealed to others. These were respectively the cases for the shaman and the local midwife. The ivenki (Cyperus spp.) were tall herbs often planted close to the entrance to the homegarden. The most frequent uses of the pinitsi and ivenki were to alleviate parturition pains, for children care (for example to bathe the babies to make them stronger against illnesses, to make babies sleep, to cure fever in children) and against sicknesses in the cultural belief.

Coca leaves (Erythroxylum coca Lam., Erythroxylaceae) were chewed together with the bark of a vine called 'chamairo' (Mussatia hyacinthina (Standl.) Sandwith, Bignoniaceae) and limestone as an alkaline additive. The chamairo bark sweetened the chew, making it more palatable. All the adults made use of this chew to avoid hunger and tiredness while working in the chacra or

Table 3 Plant parts used

\begin{tabular}{lcc}
\hline Plant parts used & $\mathbf{n}$ & $\%$ \\
\hline Leaves & 408 & 47 \\
Leaves and stem & 105 & 12 \\
Root & 80 & 9 \\
Stem & 77 & 9 \\
Bark & 61 & 7 \\
Latex & 32 & 4 \\
Leaves and bark & 11 & 1 \\
Leaves and root & 11 & 1 \\
Fruit & 9 & 1 \\
Top of caudex & 9 & 1 \\
Other & 58 & 7
\end{tabular}

walking in the forest, but only one informant cultivated a bush of coca. Usually coca leaves, chamairo bark and limestone were bought from specialized stalls in Pichanaki.

\section{The traditional healers}

During the interviews in the households four persons were generally mentioned as the most knowledgeable in the community regarding medicinal plants, they were three men and a woman: a shaman, a curandero, a tabaquero and a vaporadora. Each of them had specific competencies in the field of traditional healing.

The shaman had acquired his knowledge by visiting and paying other shamans, and he had started this apprenticeship in adult age. He was 53 years old, had a spouse but no children. By drinking a decoction of the vine 'Ayahuasca' (Banisteriopsis caapi (Spruce ex Griseb.) C.V. Morton, Malpighiaceae) he obtained visions which enabled him to diagnose diseases to his patients and resolve conflicts in the community. In this he was helped by the forest animals, whose eyes he could 'lend' by drinking the brew of Ayahuasca. Among his patients

Table 4 Ways of preparation

\begin{tabular}{lcc}
\hline Preparation & $\mathbf{n}$ & \% \\
\hline Decoction & 512 & 56 \\
Fresh & 207 & 22 \\
Steam bath & 54 & 6 \\
Emplast & 47 & 5 \\
Infusion & 25 & 3 \\
Cold water extract & 23 & 2 \\
Alcohol extract & 21 & 2 \\
Heated & 15 & 2 \\
Boiled emplast & 10 & 1 \\
Other & 8 & 1
\end{tabular}


Table 5 Ailments and diseases cured by the medicinal plant species collected in Bajo Quimiriki

\begin{tabular}{|c|c|c|c|c|}
\hline Disease category & $\begin{array}{l}\% \text { of } \\
\text { MUR }\end{array}$ & Specific diseases & No. of taxa & $\begin{array}{l}\text { Medicinal Use Reports } \\
\text { (MUR) }\end{array}$ \\
\hline Parasitic, viral, bacterial & 3.9 & Chickenpox & 3 & 3 \\
\hline and insect related & & Cholera & 4 & 4 \\
\hline \multirow[t]{8}{*}{ sicknesses } & & Fungal infections & 6 & 6 \\
\hline & & Gonorrhoea & 3 & 4 \\
\hline & & Head lies & 1 & 1 \\
\hline & & Influenza & 8 & 10 \\
\hline & & Measles & 2 & 2 \\
\hline & & Rabies & 1 & 1 \\
\hline & & To prevent flu & 1 & 3 \\
\hline & & Uta (Leishmaniasis) & 12 & 15 \\
\hline \multirow[t]{6}{*}{ Cancer, neoformations } & 2.1 & Cancer & 4 & 4 \\
\hline & & Hernia & 4 & 4 \\
\hline & & Prostate & 12 & 15 \\
\hline & & Stomach tumor & 1 & 1 \\
\hline & & To disinflamate cysts & 1 & 1 \\
\hline & & Tumors & 1 & 1 \\
\hline \multirow[t]{22}{*}{ Dermic system } & 21.8 & 'Arcoiris' & 17 & 25 \\
\hline & & 'Pokio' & 11 & 21 \\
\hline & & Browses and swellings & 20 & 39 \\
\hline & & Burned skin & 3 & 8 \\
\hline & & Dandruff & 2 & 2 \\
\hline & & Haemorrhage & 9 & 14 \\
\hline & & Acne & 6 & 7 \\
\hline & & Skin rashes & 1 & 1 \\
\hline & & Skin rashes due to allergy & 2 & 2 \\
\hline & & Skin spots & 11 & 23 \\
\hline & & Sunburn & 2 & 3 \\
\hline & & To bathe babies & 16 & 19 \\
\hline & & To disinfect wounds & 3 & 5 \\
\hline & & To enhance beard growth & 1 & 1 \\
\hline & & To enhance hair growth & 7 & 9 \\
\hline & & To prevent formation of scars & 1 & 1 \\
\hline & & To prevent hair loss & 12 & 25 \\
\hline & & To prevent white hair & 4 & 4 \\
\hline & & To strenghten hair & 1 & 1 \\
\hline & & Warts & 3 & 6 \\
\hline & & Wound healing & 21 & 53 \\
\hline & & Wounds & 4 & 7 \\
\hline \multirow[t]{13}{*}{ Digestive system } & 20.3 & Colics & 6 & 15 \\
\hline & & Diarrhoea & 17 & 26 \\
\hline & & Dysentery & 2 & 2 \\
\hline & & Emesis & 5 & 5 \\
\hline & & Gastritis & 3 & 4 \\
\hline & & Hepatitis & 1 & 1 \\
\hline & & Lack of appetite & 1 & 1 \\
\hline & & Liver-complaints & 18 & 29 \\
\hline & & Nausea & 4 & 4 \\
\hline & & Stomach ache & 33 & 57 \\
\hline & & Stomach acidity & 9 & 14 \\
\hline & & Stomach inflammation & 3 & 3 \\
\hline & & Stomach parasites & 32 & 62 \\
\hline
\end{tabular}


Table 5 Ailments and diseases cured by the medicinal plant species collected in Bajo Quimiriki (Continued)

\begin{tabular}{|c|c|c|c|c|}
\hline & & To clean the stomach & 2 & 2 \\
\hline & & To extract caried teeth & 2 & 3 \\
\hline & & To make teeth fall & 1 & 1 \\
\hline & & To protect teeth & 3 & 8 \\
\hline & & To provoke emesis & 1 & 1 \\
\hline & & Toothpain & 6 & 9 \\
\hline & & Ulcers & 6 & 10 \\
\hline \multirow{12}{*}{$\begin{array}{l}\text { Musculoskeletal and } \\
\text { articular system }\end{array}$} & 6.1 & Arthritis & 1 & 1 \\
\hline & & Bone fractures & 8 & 10 \\
\hline & & Cramps & 9 & 12 \\
\hline & & Joint dislocations & 7 & 8 \\
\hline & & Osteoarthritis & 13 & 19 \\
\hline & & Pain in the muscles after work & 2 & 3 \\
\hline & & Scapular arthritis & 4 & 6 \\
\hline & & To relax the body & 1 & 1 \\
\hline & & Inflammation & 3 & 3 \\
\hline & & Internal inflammations & 4 & 4 \\
\hline & & Internal pain 'vaso' & 3 & 3 \\
\hline & & Pains in the body & 7 & 7 \\
\hline \multirow[t]{7}{*}{ Nervous system } & 3.9 & Epilepsy & 2 & 2 \\
\hline & & Fatigue suppressor & 2 & 2 \\
\hline & & Headache & 31 & 39 \\
\hline & & Memory problems & 1 & 1 \\
\hline & & Relaxant & 2 & 2 \\
\hline & & Sleep disorders & 1 & 1 \\
\hline & & To make babies sleep & 2 & 2 \\
\hline \multirow[t]{17}{*}{ Reproductive system } & 7.2 & To abort & 10 & 22 \\
\hline & & Disinflamation following parturition & 2 & 2 \\
\hline & & Galactagogue & 1 & 1 \\
\hline & & Menstruation pain & 6 & 6 \\
\hline & & Ovary infection & 1 & 1 \\
\hline & & Ovary inflammation & 11 & 17 \\
\hline & & Penis extender & 3 & 4 \\
\hline & & Sexual invigorator for men & 6 & 9 \\
\hline & & To correct irregular menstruation & 2 & 3 \\
\hline & & To enhance women fertility & 4 & 5 \\
\hline & & To give birth rapidly & 3 & 3 \\
\hline & & To give birth without pain & 3 & 3 \\
\hline & & To give birth rapidly and not feel the pain & 3 & 3 \\
\hline & & To lift up testicles & 1 & 2 \\
\hline & & Contraceptive & 5 & 5 \\
\hline & & To release the placenta after giving birth & 1 & 2 \\
\hline & & Vaginal infection & 3 & 3 \\
\hline \multirow[t]{5}{*}{ Respiratory system } & 1.9 & Asthma & 1 & 1 \\
\hline & & Bronchitis & 1 & 4 \\
\hline & & Cold & 3 & 6 \\
\hline & & Cough & 7 & 12 \\
\hline & & Tubercolosis & 1 & 1 \\
\hline Snake/spider/ & 3 & Ant bites & 1 & 1 \\
\hline \multirow[t]{3}{*}{ insect bites } & & Insect bites & 6 & 19 \\
\hline & & Snake bites & 13 & 16 \\
\hline & & Spider bites & 2 & 2 \\
\hline
\end{tabular}


Table 5 Ailments and diseases cured by the medicinal plant species collected in Bajo Quimiriki (Continued)

\begin{tabular}{|c|c|c|c|c|}
\hline \multirow[t]{3}{*}{ Fever/Malaria } & 4.9 & Fever & 16 & 33 \\
\hline & & High Fever & 1 & 3 \\
\hline & & Malaria & 10 & 26 \\
\hline \multirow[t]{4}{*}{ Urinary system } & 4.8 & Infection of urinary duct & 5 & 7 \\
\hline & & Inflammation of urinary duct & 2 & 2 \\
\hline & & Kidney-complaints & 24 & 50 \\
\hline & & For babies to stop wetting the bed & 2 & 2 \\
\hline \multirow[t]{18}{*}{ Cultural belief system } & 15.9 & Chacho & 14 & 23 \\
\hline & & Mal agua & 1 & 1 \\
\hline & & Mal aire & 51 & 82 \\
\hline & & Seeing shadows & 6 & 8 \\
\hline & & To bathe babies & 16 & 19 \\
\hline & & To become adult & 1 & 1 \\
\hline & & To bring good luck & 1 & 1 \\
\hline & & To connect with the spirits of the forest & 1 & 2 \\
\hline & & To diagnose illnesses & 1 & 2 \\
\hline & & To get ones spirit back & 2 & 2 \\
\hline & & To make babies talk & 1 & 1 \\
\hline & & To make babies walk fast & 8 & 9 \\
\hline & & To protect from witchery and illness & 2 & 4 \\
\hline & & To see other places & 1 & 2 \\
\hline & & To see who is the responsible for a witchery & 1 & 1 \\
\hline & & To strenghten newborn babies & 9 & 11 \\
\hline & & Used by tobacco healer & 1 & 6 \\
\hline & & Witchery & 20 & 27 \\
\hline \multirow[t]{22}{*}{ Other } & 5 & Against laziness in children & 1 & 1 \\
\hline & & Alcoholism & 2 & 4 \\
\hline & & Anemia & 2 & 2 \\
\hline & & Cholesterol & 1 & 1 \\
\hline & & Earache & 3 & 3 \\
\hline & & Eye infection & 3 & 9 \\
\hline & & Eye inflammation & 4 & 4 \\
\hline & & General not well being & 1 & 1 \\
\hline & & Swallen feet & 4 & 8 \\
\hline & & To attract men & 2 & 2 \\
\hline & & To attract the other sex & 3 & 3 \\
\hline & & To attract women & 3 & 4 \\
\hline & & To be faithful to the partner & 1 & 1 \\
\hline & & To boost immune system & 1 & 1 \\
\hline & & To gain weight & 1 & 1 \\
\hline & & To live long & 1 & 1 \\
\hline & & To loose weight & 2 & 2 \\
\hline & & To prevent ageing & 5 & 8 \\
\hline & & To stop dreaming dead people & 1 & 1 \\
\hline & & To strenghten elderly people & 2 & 2 \\
\hline & & To strenghten the body & 3 & 3 \\
\hline & & Violent men & 1 & 1 \\
\hline
\end{tabular}

The ailments and diseases are divided into disease categories with respective number of species. 


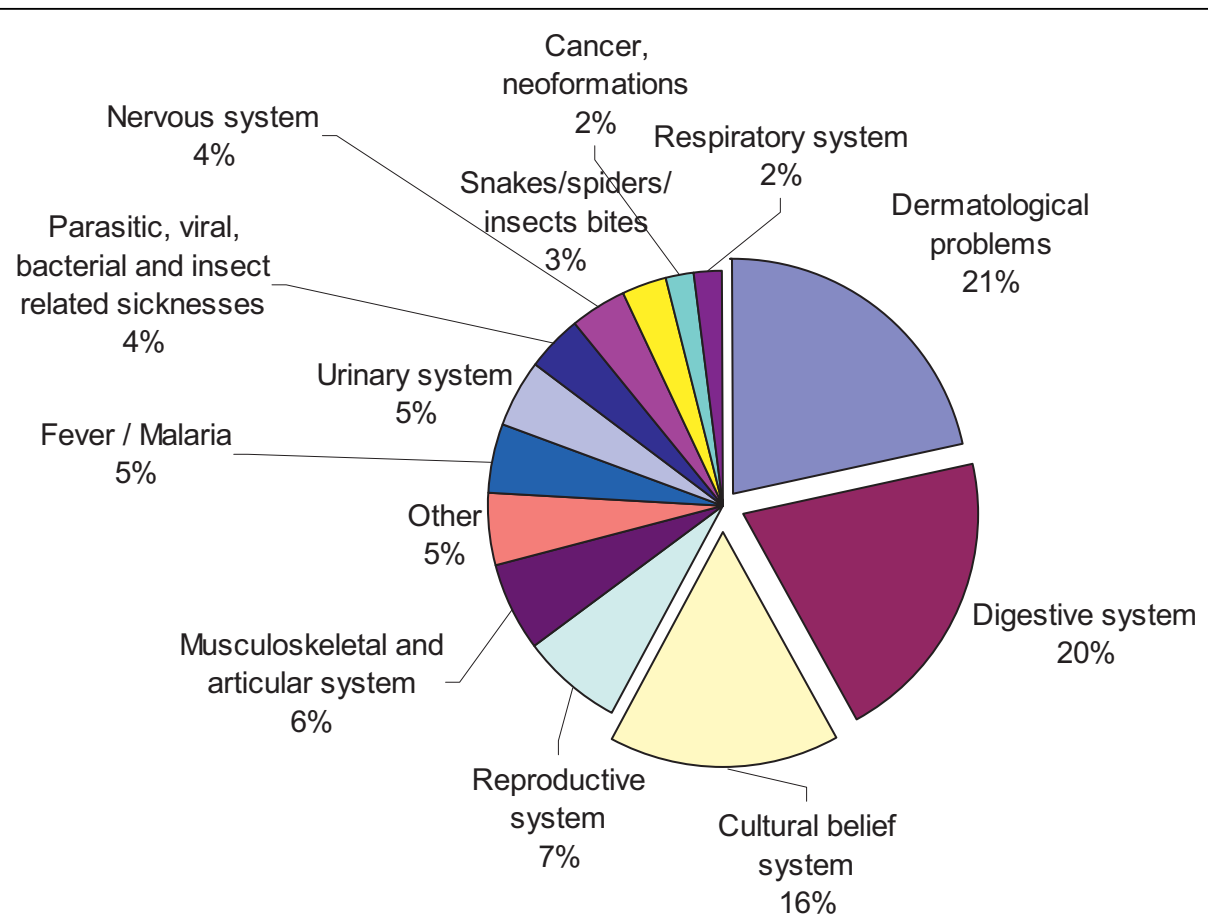

Figure 3 Percentage of the medicinal use reports of the $\mathbf{4 0 2}$ medicinal plants to disease categories. Dermatological problems, problems related to the digestive system and cultural belief system were among the most frequent ailments treated with the medicinal plants, representing $57 \%$ of all the medicinal use reports $(n=1268)$.

there were also many 'colonos', non-indigenous people, coming from as far as Lima. Maybe in order to attract even more customers, the shaman had included among his practices also fortune-telling.

The curandero was a 69 years old man, many villagers said that he had knowledge and powers like the shaman, but he was very discrete and did not confirm this when interviewed. Apparently he also received customers from the city.

The tabaquero was a man in his seventies, who did not speak Spanish, possibly by own choice. He was specialized in the healing with tobacco leaves performed by blowing smoke on the body of the ill patients.

The woman was a renowned vapour healer in her fifties. In the Asháninka communities, this healing practice is in the domain of skilled women who start their apprenticeship in an early age, following a strict diet. During the time of the fieldwork she became ill and was taken to another community to recover. Her family did not exclude that her illness could derive from the envy of one of the other healers.

A lady aged 71 proved to have an extensive knowledge of medicinal plants during the forest walk, although she was not mentioned as frequently as the four healers by the other villagers. She worked from time to time as a midwife, especially for women in the city.

\section{Knowledge variations}

Eight hundred and sixty four independent events (72 pre-marked plants $\times 12$ informants) were recorded during the forest walks in the community reserve, with six informants for each gender. An 'event' is here defined as "the process of asking one informant on one day about the uses they know for one species" [17]. All the informants, with varying extent, spontaneously pointed out also at plants that were not pre-marked and described their medicinal application. The number of these plants is 91 for men and 96 for women. The results from the forest walks are shown in Figure 4. Women described a medicinal application in a higher number of events: they scored a total of 310 record of use versus 206 total records of use by men. The difference is mainly given by the 72 pre-marked plants of which women described one or more medicinal use in $49.5 \%$ of the events, while men did so in $26.6 \%$ of the events. The difference is statistically significant $\left(\chi^{2}=47.1429, \mathrm{p}\right.$-value $\left.=6.6 \mathrm{e}-12\right)$. In the group of men the oldest informant (55 years old) was the most knowledgeable, indicating a medicinal use for 30 out of the 72 pre-marked medicinal plants; also in the group of women the most knowledgeable informant was the oldest person (71 years old), who indicated a medicinal use for 57 of the 72 pre-marked medicinal plants. In the group of women two other 
Table 6 Diseases most often occurring in the informant's families and the species used in their cure

\begin{tabular}{|c|c|c|}
\hline $\begin{array}{l}\text { Most mentioned } \\
\text { diseases in the } \\
\text { community }\end{array}$ & $\begin{array}{l}\text { Percentage of informants } \\
\text { reporting disease in their family }\end{array}$ & Species used to cure the disease in the community \\
\hline Mal aire & $62 \%$ & $\begin{array}{l}\text { Acanthaceae: Justicia appendiculata Apocynaceae: Himatanthus sucuuba Araceae: } \\
\text { Anthurium dombeyanum, Philodendron plowmanii Arecaceae:Iriartea cf. deltoidea. } \\
\text { Aspleniaceae: Asplenium sp. Asteraceae: Munnozia hastifolia, Tagetes erecta, Trixis } \\
\text { divaricata Bignoniaceae: Mansoa alliacea Combretaceae: Terminalia sp. Costaceae: } \\
\text { Costus spp. Cucurbitaceae: Momordica charantia Cyclanthaceae: Cyclanthus } \\
\text { bipartitus, Carludovica palmata Euphorbiaceae: Ricinus communis Fabaceae: } \\
\text { Desmodium sp., Inga sp. Gesneriaceae: Corytoplectus speciosus Lamiaceae: Ocimum } \\
\text { basilicum Nyctaginaceae: Neea sp. Piperaceae: Piper aduncum, Piper cf. } \\
\text { longestylosum, Piper spp. Rubiaceae: Psychotria poeppigiana Solanaceae: Brunfelsia } \\
\text { grandiflora, Cestrum hediondinum, Nicotiana tabacum Urticaceae: Urera cf. baccifera, } \\
\text { Urera cf. capitata, Urera laciniata Verbenaceae: Lippia alba Zingiberaceae: Costus } \\
\text { sp. }\end{array}$ \\
\hline Malaria & $38 \%$ & $\begin{array}{l}\text { Asteraceae: Bidens sp., Clibadium sylvestre, Hebeclinum macrophyllum, Munnozia } \\
\text { hastifolia Cucurbitaceae: Momordica charantia Solanaceae: Cestrum hediondiunum } \\
\text { Verbenaceae: Phyla sp., Verbena sp. }\end{array}$ \\
\hline Diarrhoea & $31 \%$ & $\begin{array}{l}\text { Apocynaceae: Tabernaemontana sp. Asteraceae: Acmella oleracea, Bidens sp., } \\
\text { Hebeclinum macrophyllum Bixaceae: Bixa orellana Chenopodiaceae: Chenopodium } \\
\text { ambrosioides Cucurbitaceae: Momordica charantia Cyperaceae: Cyperus sp. } \\
\text { Euphorbiaceae: Jatropha curcas Lauraceae: Aniba canelilla Menispermaceae: } \\
\text { Chondrodendron tomentosum Myrtaceae: Psidium guajava Solanaceae: Physalis } \\
\text { pubescens, Solanum americanum Verbenaceae: Verbena sp. }\end{array}$ \\
\hline Chacho & $23 \%$ & $\begin{array}{l}\text { Asteraceae: Acmella oleracea, Eclipta prostrata, Mikania micrantha, Senecio sp. } \\
\text { Tessaria integrifolia Cyperaceae: Eleocharis sp. Equisetaceae: Equisetum giganteum } \\
\text { Fabaceae: Inga sp. Maranthaceae: Calathea sp. Onagraceae: Ludwigia peploides }\end{array}$ \\
\hline Headache & $15 \%$ & $\begin{array}{l}\text { Anacardiaceae: Tapirira guianensis Araceae: Anthurium dombeyanum Asteraceae: } \\
\text { Mikania micrantha Campanulaceae: Centropogon sp. Euphorbiaceae: Alchornea sp. } \\
\text { Fabaceae: Phaseolus sp. Piperaceae: Piper sp. Poaceae: Acroceras cf. zizanoides, } \\
\text { Chusquea sp., Rubiaceae: Hamelia patens, Psychotria poeppigiana Solanaceae: } \\
\text { Cestrum hediondinum, Nicotiana tabacum, Solanum americanum, Solanum } \\
\text { mammosum, Solanum spp. Urticaceae: Urera cf. Baccifera Verbenaceae: Lantana } \\
\text { camara }\end{array}$ \\
\hline Intestinal parasites & $15 \%$ & $\begin{array}{l}\text { Amaranthaceae: Iresine diffusa Annonaceae: Annona muricata Apocynaceae: } \\
\text { Himatanthus sucuuba Araceae: Anthurium dombeyanum, Anthurium kunthii, } \\
\text { Homalonema crinipes, Philodendron brandtianum, Philodendron deflexum, } \\
\text { Philodendron ernesti, Philodendron hylaeae, Philodendron plowmanii, Rhodospatha } \\
\text { latifolia, Syngonium podophyllum Arecaceae: Bactris gasipaes Asteraceae: Ageratum } \\
\text { conyzoides, Bidens sp., Hebeclinum macrophyllum Bignoniaceae: Tynanthus } \\
\text { polyanthus Chenopodiaceae: Chenopodium ambrosioides Cucurbitaceae: } \\
\text { Momordica charantia Elaeocarpaceae: Sloanea sp. Euphorbiaceae: Alchornea sp., } \\
\text { Jatropha curcas Fabaceae: Inga sp. Melastomataceae: Miconia sp. } \\
\text { Menispermaceae: Chondrodendron tomentosum Moraceae: Artocarpus altilis } \\
\text { Solanaceae: Physalis pubescens }\end{array}$ \\
\hline
\end{tabular}

Table 7 Medicinal plants used in the treatment of Leishmaniasis

\begin{tabular}{ll}
\hline Species & Plant part used \\
\hline Anacardium occidentale & Fruit pericarp oil \\
Tapirira guianensis & Bark \\
Asclepias curassavica & Latex \\
Erechtites hieracifolius & Leaves \\
Jacaranda copaia & Ashes \\
Alchornea sp. & Latex \\
Croton lechleri & Latex \\
Jatropha curcas & Latex \\
Inga sp. & Bark \\
Psychotria poeppigiana & Leaves \\
Urera cf. caracasana & Sap \\
\hline
\end{tabular}

informants aged 36 and 55 were particularly knowledgeable indicating a medicinal use for 49 and 52 of the 72 pre-marked medicinal plants each. Age explains $46 \%$ of the variation of knowledge between the 12 informants. The correlation of the variables is statistically significant, with a 95 percent level of confidence ( $\mathrm{p}$-value $=0.015)$. Nevertheless if we consider the group of men and women separately, we see that for men age explaines $68 \%$ of the variation and the correlation between the variables is still statistically significant at 95 percent level of confidence $(p$-value $=0.042)$, while for women age explains only $35 \%$ of the variation in the group and the correlation between age and knowledge is not statistically significant (see Discussion). 


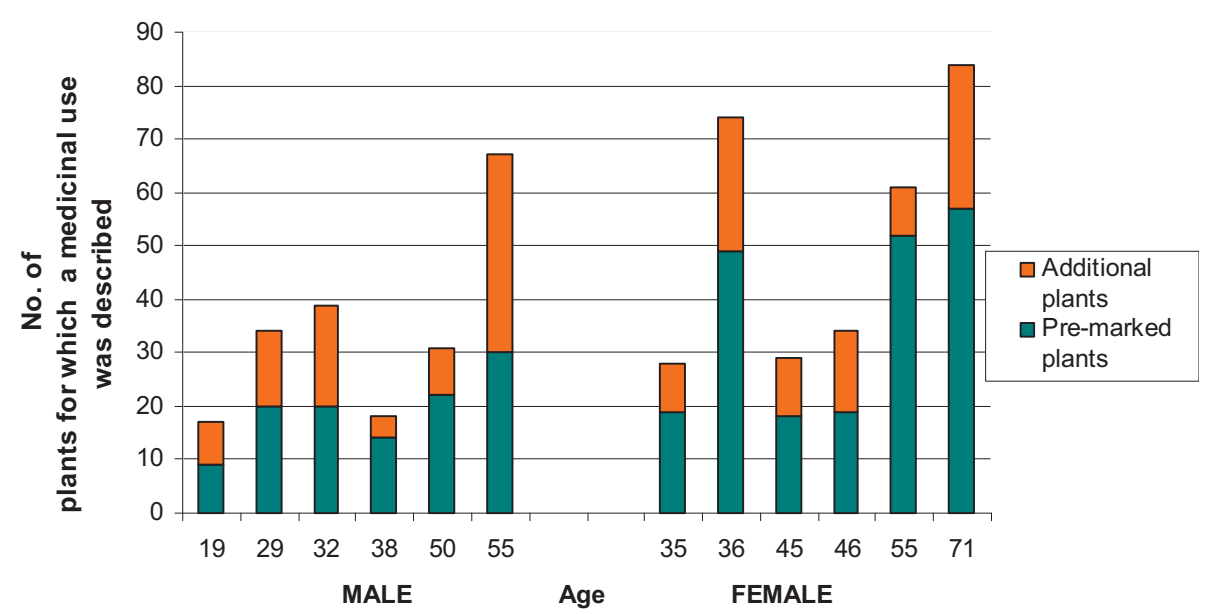

Figure 4 Medicinal plants' knowledge variation during the forest walk. Number of medicinal plants recognised by each informant on the track in the forest. Female informants identified and described the medicinal use of $49.5 \%$ of the pre-marked plants, while men did so for $26.6 \%$ of the pre-marked plants. All the informants indicated also a number of additional medicinal plants.

We registered a great variation of uses attributed to the same species by different informants, even for those plants that were well known in the community (whose medicinal use was reported by more than 10 informants). As an example Dieffenbachia costata Klotzsch ex Schott (Araceae) was reported by 23 informants against 10 different conditions/diseases (see Table 8 and Additional file 1).

\section{Medicinal plants known by the children}

The children of the $5^{\text {th }}$ and $6^{\text {th }}$ grade of the elementary school stated that the persons that knew most about medicinal plants in their families were the grandfathers. Out of seventeen children in the class, two (a boy and a girl) declared that they would have liked to become a shaman. The class listed 27 medicinal plants with their respective uses and preparations, which are displayed in Table 9. The children knew the great majority of plants with a Spanish name, only three plants were called with an Asháninka name. They were able to describe the way of preparation of 14 of the 27 plants. Twenty plants were commonly growing in or around the homegardens and ten of these were actively cultivated. The botanical names of the table have been inferred from the vernacular name and therefore in some cases more than one species might correspond to a vernacular name.

\section{Comparison with the Yanesha ethnic group}

A recent study published on the medicinal concepts and plants uses among the Yanesha group [60] allows a comparison with the Asháninka of our study. The data on the Yanesha were collected in three communities in the Oxapampa province (Pasco Region) over a period of three years, working with 30 informants. Six hundred and seven herbarium samples were collected all together, and a total of two hundred and forty nine species were designated as medicinal [60]. Our data on the Asháninka were collected over a period of three months in one community working with a total of 37 adult indigenous informants and 17 children. In this short period we collected a total of 402 herbarium samples corresponding to at least two hundred and eight different species (Additional file 1).

Comparing the two sets of data we found an overlap of 33 species (16\% of our 208 identified species). In $64 \%$ of the cases the plants were used for the same disease or condition (see Table 10).

Ninety seven percent of the specific uses reported by the Yanesha were also reported by the Asháninka, including particular diseases like 'arcoiris' (skin problems occurring when bathing in the river under a rainbow). The forms of preparation of the remedies were also very alike, including among others steam baths or application of leaf sap in the eyes. In both ethnic groups plants from the genus Piper (Piperaceae) were very often prepared in the form of a steam bath against 'mal aire'.

\section{Discussion}

Medicinal plants - diversity, life form and habitat

The families Asteraceae, Araceae, Rubiaceae, Euphorbiaceae, Solanaceae and Piperaceae, were the most important families in terms of number of taxa with medicinal uses in the community. A recent study among the Yanesha of the Selva Central reported similar results, with exception of the Asteraceae which was represented in their pharmacopoeia with only seven species [60]. According to Vásquez Martínez et al. [61] these families are also the most commonly 
Table 8 Medicinal plants reported by at least 10 informants and their respective uses

\begin{tabular}{|c|c|c|}
\hline Scientific name (Voucher N.) & $\begin{array}{c}\text { No. of } \\
\text { Informants }\end{array}$ & Medicinal uses \\
\hline $\begin{array}{l}\text { Dieffenbachia costata }(0704,0605 \\
2813, \mathrm{R} 38, \mathrm{R} 77)\end{array}$ & 23 & $\begin{array}{l}\text { Insect bites, Bone pain, Bronchitis, Cold, Cough, Snake bites, Wounds, To protect from sorcery and } \\
\text { illness, Influenza, Toothache. }\end{array}$ \\
\hline $\begin{array}{l}\text { Uncaria guianensis (R19, PA3, R56, } \\
4015,4017)\end{array}$ & 19 & $\begin{array}{l}\text { To abort, Osteoarthritis, Cancer, Cold, Inflammation, Kidney-complaints, Liver-complaints, Ovary } \\
\text { inflammation, Penis extender, Prostate, Stomach ache, Ulcers. }\end{array}$ \\
\hline $\begin{array}{l}\text { Cestrum hediondinum }(0607,2904, \\
\text { R91) }\end{array}$ & 17 & Fever, Headache, Malaria, Stomach ache, Sorcery. \\
\hline Homalomena crinipes (R4, R50) & 15 & To clean the stomach, Toothache, To Abort, To protect teeth, Intestinal parasites. \\
\hline Acmella oleracea $(0203, \mathrm{PL} 22)$ & 15 & $\begin{array}{l}\text { Sunburn, 'Pokio', Browses and swellings, 'Chacho', Diarrhoea, Insect bites, Toothache, Earache, } \\
\text { 'Arcoiris'. }\end{array}$ \\
\hline $\begin{array}{l}\text { Hebeclinum macrophyllum (R33, } \\
\text { 0107, R7) }\end{array}$ & 14 & $\begin{array}{l}\text { Malaria, Stomach ache, Infection of urinary duct, Liver-complaints, Intestinal parasites, Chickenpox, } \\
\text { Diarrhoea, Stomach acidity, Colics. }\end{array}$ \\
\hline Erechtites hieraciifolius (0211, PL23) & 14 & Skin spots, Acne, Uta (Leishmaniasis), To prevent hair loss. \\
\hline $\begin{array}{l}\text { Chenopodium ambrosioides (PL1, } \\
0206,0602,0907)\end{array}$ & 14 & Intestinal parasites, Colics, Fever, Diarrhoea, To bathe babies. \\
\hline Piper aduncum (R10, 0603, 2806) & 14 & $\begin{array}{l}\text { Cramps, High Fever, 'Mal aire', Menstruation pain, Stomach ache, Ulcers, Vaginal infections, Vomit, } \\
\text { Sorcery, Wound-healing. }\end{array}$ \\
\hline Xanthosoma poeppigii (R89) & 13 & Wound healing, Bone fractures. \\
\hline Momordica charantia $(0108,2901)$ & 13 & $\begin{array}{l}\text { Malaria, Stomach ache, Stomach acidity, Fever, Diarrhoea, Intestinal parasites, Kidney-complaints, } \\
\text { Mal aire. }\end{array}$ \\
\hline Verbena sp. $(2920,3701)$ & 13 & Malaria, Stomach ache, Diarrhoea, To bathe babies. \\
\hline $\begin{array}{l}\text { Syngonium podophyllum (R9, } \\
\text { 2814, DH09, DH04) }\end{array}$ & 12 & $\begin{array}{l}\text { To correct irregular menstruation, To extract caried teeth, Toothache, Contraceptive, Intestinal } \\
\text { parasites, Joint dislocations, Anaemia, Osteoarthritis, Browses and swellings. }\end{array}$ \\
\hline Munnozia hastifolia (R27) & 12 & $\begin{array}{l}\text { Cholera, Sorcery, Kidney-complaints, Gastritis, Wounds, Malaria, To stop dreaming dead people, } \\
\text { Stomach ache, 'Mal aire', Fever, Cholesterol. }\end{array}$ \\
\hline Croton lechleri (0609) & 12 & $\begin{array}{l}\text { Wound healing, Ulcers, Liver-complaints, Uta (Leishmaniasis), Dysentery, Disinflamation following } \\
\text { parturition. }\end{array}$ \\
\hline Chaptalia nutans (2811, 2908, R34) & 11 & Malaria, Stomach ache, Diarrhoea, Intestinal parasites. \\
\hline Bixa orellana $(2810,2907)$ & 11 & $\begin{array}{l}\text { To prevent hair loss, Eye infection, Prostate, Diarrhoea, Wounds, Stomach inflammation, Cancer, } \\
\text { Kidney-complaints, To bathe babies. }\end{array}$ \\
\hline $\begin{array}{l}\text { Xiphidium caeruleum (R55,0606, } \\
\text { R41, 4004, 4007) }\end{array}$ & 11 & $\begin{array}{l}\text { Bone fractures, Joint dislocations, Browses and swellings, To strenghten hair, To enhance hair } \\
\text { growth, 'Mal agua', To bathe babies. }\end{array}$ \\
\hline Hamelia patens $(2803,2903)$ & 11 & To disinfect wounds, Browses and swellings, Stomach ache, Headache. \\
\hline Urera cf. Baccifera (R90, R92) & 11 & $\begin{array}{l}\text { Mal aire', Kidney-complaints, Seeing shadows, Headache, Pain in the muscles after work, General } \\
\text { not well being, Cramps. }\end{array}$ \\
\hline Asclepias curassavica (R29) & 10 & Wound healing, Uta (Leishmaniasis), Eye inflammation. \\
\hline $\begin{array}{l}\text { Anthurium dombeyanum (R23, } \\
\text { R64) }\end{array}$ & 10 & $\begin{array}{l}\text { Snake bites, 'Mal aire', To attract men, Headache, To enhance hair growth, Intestinal parasites, } \\
\text { Infection of urinary duct, Stomach ache, Cough, Seeing shadows. }\end{array}$ \\
\hline $\begin{array}{l}\text { Bidens pilosa (0207, R3, L125, PL13, } \\
\text { ROM1) }\end{array}$ & 10 & $\begin{array}{l}\text { Burned skin, To prevent formation of scars, To give birth rapidly, To prevent hair loss, Dandruff, } \\
\text { Contraception, To make babies walk fast, Skin spots. }\end{array}$ \\
\hline Mikania micrantha (PL18) & 10 & Headache, Osteoarthritis, Scapular arthritis, 'Chacho', Sorcery, Arcoiris, 'Pokio', Alcoholism, Acne. \\
\hline Tessaria integrifolia (0102, PL21) & 10 & Kidney-complaints, Ovary inflammation, General not well being, Swollen feet, 'Pokio', 'Chacho'. \\
\hline Nicotiana tabacum (0601) & 10 & Insect bites, Used by tobacco healer to cure patients, 'Mal aire', Headache. \\
\hline Urera laciniata $(R 32,2817)$ & 10 & $\begin{array}{l}\text { Sorcery, Kidney-complaints, Prostate, Cramps, Sorcery, 'Mal aire', Osteoarthritis, Fever, Measles, } \\
\text { Improve male libido. }\end{array}$ \\
\hline
\end{tabular}

encountered in the Peruvian Selva Central. At the same time these families are often targeted during taxonomic approaches to drug discovery for their rich content of secondary compounds like steroids and alkaloids [46] and many of their species are wellknown South American medicinal plants [49,50]. The prevalence of Asteraceae among local pharmacopoeias is reported in many other South American studies $[25,27,62,63]$. The Araceae family was of particular importance in the community: 17 species were indicated for medical use by the informants, while the previously mentioned study among the Yanesha [60] recorded the medicinal use of ten species in this family. The Araceae, especially those in the genus Philodendron, were often called 'kainto': the same indigenous name was also reported in studies among the Ashéninka of the Ucayali and Ashéninka del Gran Pajonal [29]. The results from the comparison with the 
Table 9 Medicinal plants known by the children of the 5th and 6th grade of the elementary school

\begin{tabular}{|c|c|c|c|c|c|}
\hline & Vernacular name & Scientific name & Family & Use & Preparation* \\
\hline & Pusanga & - & - & To attract the other sex & - \\
\hline \multirow[t]{2}{*}{$\hookrightarrow$} & Chupa sangre & Hamelia patens & Rubiaceae & Wounds, colics & - \\
\hline & Cuatro esquinas & - & - & Browses & - \\
\hline 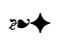 & Verbena & Verbena sp. & Verbenaceae & Malaria & - \\
\hline 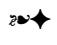 & Matico & Piper aduncum, Piper sp. & Piperaceae & Wounds, fever & Bw \\
\hline$\hookrightarrow$ & Amargón & Hebeclinum macrophyllum & Asteraceae & Colics, diarrhoea & $\mathrm{Bw}, \mathrm{Bd}$ \\
\hline$\hookrightarrow$ & Suelda suelda & Cissus gongylodes, Commelina sp. & Vitaceae & Bone pain & Em \\
\hline \multirow[t]{2}{*}{$\hookrightarrow$} & Paico & Chenopodium ambrosoides & Chenopodiaceae & Belly/Stomach ache, colics, diarrhoea & - \\
\hline & Oja de Murcielago & Munnozia hastifolia & Asteraceae & Ovary inflammation, belly ache & $\mathrm{Bd}$ \\
\hline$\hookrightarrow$ & Llantén & Plantago major & Plantaginaceae & Ovary inflammation, belly ache & - \\
\hline \multirow[t]{3}{*}{ 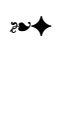 } & Sangre de grado & Croton lechleri & Euphorbiaceae & Wounds & $L x$ \\
\hline & Sachahuasca & - & - & Kidney-complaints & $\mathrm{Bd}$ \\
\hline & Uña de gato & Uncaria guianensis Uncaria tomentosa & Rubiaceae & Wounds, kidney-complaints & $\mathrm{Bd}$ \\
\hline \multirow[t]{2}{*}{24} & Pan de arbol & Artocarpus altilis & Moraceae & Hernia & $L x$ \\
\hline & Huampo Blanco & Heliocarpus americanus & Tiliaceae & To purify the body & $\mathrm{Bd}$ \\
\hline 24 & Platano & Musa paradisiaca & Musaceae & Wounds, haemorrhage & $\mathrm{Sa}$ \\
\hline \multirow[t]{2}{*}{ 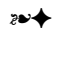 } & Pepa de palta & Persea americana & Lauraceae & Diarrhoea & $\mathrm{Cbd}$ \\
\hline & 'Okilia' & - & - & Eye infection & Cs \\
\hline 24 & Achiote & Bixa orellana & Bixaceae & 'Susto', eye infection & - \\
\hline$\hookrightarrow$ & 'Porokishi' & Vernonia sp. & Asteraceae & Wounds & - \\
\hline 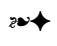 & Tabaco & Nicotiana sp. & Solanaceae & 'Susto', sorcery, used by curanderos & - \\
\hline 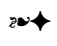 & Piñon & Jatropha curcas & Euphorbiaceae & Parasites & - \\
\hline 24 & Guajaba & Psidium guajava & Myrtaceae & Diarrhoea, stomach ache & $\mathrm{Bd}$ \\
\hline$\hookrightarrow$ & Chanca piedra & Phyllanthus niruri Phyllanthus orbiculatus & Euphorbiaceae & Wounds, malaria & - \\
\hline$\hookrightarrow$ & Lengua de perro & Chaptalia nutans, Asplenium serratum & Asteraceae & Stomach ache, ovary inflammation & - \\
\hline$\hookrightarrow$ & Cola de caballo & Xiphidium caeruleum & Haemodoraceae & 'Mal aire', sorcery, to enhance hair growth & St, Bw \\
\hline \multirow[t]{4}{*}{ 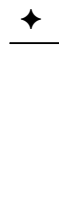 } & Pajaro bobo & Tessaria integrifolia & Asteraceae & Head ache & - \\
\hline & cultivated in ho & gardens & & & \\
\hline & $\uparrow$ : grows wild in $\mathrm{h}$ & negardens & & & \\
\hline & $\begin{array}{l}{ }^{*} \text { Bw: boil and wash } \\
\text { the wound; Cbd: } \mathrm{cr}\end{array}$ & ith the decoction; Bd: boil & ecoction; Em: er & ast; $L x$ : apply the fresh latex on the woun & Sa: apply sap on \\
\hline
\end{tabular}

Yanesha showed that the two ethnic groups shared at least $16 \%$ of the reported pharmacopoeia and they had in common the great majority of their diseases and traditional healing practices. The fact that none of the names were in common suggests that the communities independently discovered these plants.

In ethnobotanical studies the prevalent life-form of medicinal plants varies between herbs $[64,65]$ and trees [66], with leaves and stems as the most commonly used plant parts $[25,64,66,67]$, this is in agreement with the observations in the Bajo Quimiriki community. Using leaves is less destructive than bark stripping or digging out the roots.

Only 5 of the medicinal plants identified to species or genus (301) were exotics (2\%), while other studies reported percentages of exotic plants among the local pharmacopoeias as high as $37.5 \%$ in Loja and ZamoraChinchipe (Ecuador) [20] and 26.5\% in Rama midwifery (Nicaragua) [68]. This indicates that the Asháninka in this community have a strong tradition of medicinal plants and that an eventual plant exchange between communities involves mainly local species. The families of the plants identified only to family level are all common in Peru. The forty-seven plants which were not identified were collected for the great majority in the forest and are therefore very likely to be native species, as all the plant species identified as exotics were found in the homegardens and were well known introduces species.

Our fieldwork was limited to 3 months in the area, therefore we probably missed some annual plants that were not found during our stay. The short fieldwork also decreased our possibilities to collect fertile voucher specimens and made the identification of many plants challenging.

\section{Plants of cultural and social use}

Regarding the plants locally called "ivenki" and "pinitsi", the use of ivenkis among the Asháninka and Ashéninka 
Table 10 Comparison between medicinal use of the same species by the Asháninka of Bajo Quimiriki and the neighbouring group Yanesha, based on data from the present study and Valadeau et al. 2010 [60]

\begin{tabular}{|c|c|c|}
\hline $\begin{array}{l}\text { Botanic family } \\
\text { Scientific determination } \\
\text { (herbarium number) }\end{array}$ & $\begin{array}{l}\text { Use by the Yanesha } \\
\text { (from Valadeau et al. 2010) }\end{array}$ & Use in the Asháninka community of Bajo Quimiriki \\
\hline \multicolumn{3}{|l|}{ Amaranthaceae } \\
\hline $\begin{array}{l}\text { Iresine diffusa Humb. \& } \\
\text { Bonpl. ex Willd. (CA06, } \\
\text { ISO2, LI4, PE2) }\end{array}$ & Malaria & Intestinal parasites, liver complaints \\
\hline \multicolumn{3}{|l|}{ Araceae } \\
\hline $\begin{array}{l}\text { Syngonium podophyllum } \\
\text { Schott (R9, 2814, DH09, } \\
\text { DH04) }\end{array}$ & Wounds, burns & $\begin{array}{l}\text { To correct irregular menstruation, to extract caried teeth, } \\
\text { toothache, contraceptive, Intestinal parasites, joint } \\
\text { dislocations, anaemia, osteoarthritis, browses and swellings }\end{array}$ \\
\hline $\begin{array}{l}\text { Philodendron ernestii Engl. } \\
\text { (FL25) }\end{array}$ & Intestinal parasites & Intestinal parasites \\
\hline
\end{tabular}

\section{Arecaceae}

Bactris gasipaes Kunth Mal aire (DH05)

Intestinal parasites

\section{Asteraceae}

Bidens pilosa L. (0207, R3, Flu, muscular pain, liver pain, fever, malaria, urinary and LI25, PL13, ROM1, FL3) uterine infections, trauma, to have an eternal love

Mikania micrantha Kunth (PL18)

Mal aire, protection against the illnesses from the river, throat pain

Munnozia hastifolia

(Poepp.) H.Rob. \& Brettell (R27)

General body pain, stomach ache, gynaecological disorder, kidney pain, leishmaniasis, infected wounds, to clean the baby just after birth, stomach infection diarrhoea, liver pain, protection for children

Tessaria integrifolia Ruiz \& Liver and kidneys pain, urinary inflammation, prostatic Pav. (0102, PL21)

pain, throat pain

\section{Bignoniaceae}

Jacaranda copaia D.Don (R93)

Malaria or fever preventive, infected pimples, itching dermatosis, leishmaniasis

Mansoa alliacea (Lam.) A.

H. Gentry (4022)

Diarrhoea with stomach pain, fever, flu, cold,

rheumatic pain, skin ulcers, boils

\section{Bixaceae}

Bixa orellana L. (2810, Heart pain, prostate inflammation, anorexia, eye pain 2907)

\section{Chenopodiaceae}

\section{Chenopodium}

ambrosioides L. (PL1, 0206

0602, 0907)

\section{Cyclanthaceae}

Cyclanthus bipartitus Poit. Ant's bite (fever)

(R87)

\section{Euphorbiaceae}

Euphorbia heterophylla L. (WA01, 2915)

Manihot esculenta Crantz (2914)

Abdominal pain with gas, intestinal parasites

\section{Fabaceae}

Calliandra angustifolia Spruce ex Benth. (1002, 0604)

\section{Gleicheniaceae}

Dicranopteris pectinata

(Willd.) Underw. (PE29)

Haemodoraceae

Xiphidium caeruleum Aubl. Hair care, wounds (R55,0606, R41, 4004,

\section{Leishmaniasis}

Mal aire: muscular pain

\section{General malaise}

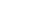

\section{Tiredness of old persons, stomach ache, purgative}

Burned skin, to prevent formation of scars, to give birth rapidly, to prevent hair loss, dandruff, contraceptive, to make babies walk fast, skin spots

Headache, arthritis, chacho, sorcery, arcoiris, pokio alcoholism, acne

Cholera, sorcery, kidney-complaints, gastritis, wounds, malaria, to stop dreaming dead people, stomach ache, mal aire, fever, cholesterol

Kidney-complaints, ovary inflammation, general not well being, swallen feet, 'pokio', 'chacho'

Leishmaniasis, wound healing

Mal aire

To prevent hair loss, eye infection, prostate, diarrhoea, wounds, stomach infection, cancer, kidney-complaints, to bathe babies

Intestinal parasites, colics, fever, diarrhoea, to bathe babies

To prevent hair loss, sorcery, mal aire

Wound healing, eye infection

To cure bites of dogs with rabies

To strenghten newborn babies, to make babies walk fast, to strenghten elderly people

To strenghten newborn babies

Bone fractures, joint dislocations, browses and swellings, to strenghten hair, to enhance hair growth, 'mal agua' to bathe babies 
Table 10 Comparison between medicinal use of the same species by the Asháninka of Bajo Quimiriki and the neighbouring group Yanesha, based on data from the present study and Valadeau et al. 2010 [60] (Continued)

\section{Iridaceae}

Eleutherine bulbosa (Mill.) Intestinal haemorrhage, vomiting with blood, fever Urb. $(2103,2909)$

\section{Malvaceae}

Gossypium barbadense L. (0508, 0906)

Sida rhombifolia L. (WA02, 2924)

\section{Myrtaceae}

Psidium guajava L. (2930)

Piperaceae

Piper peltatum (L.) Miq. (2911, 0114, 4003)

Piper aduncum L. (R10,0603, 2806)

\section{Rubiaceae}

Hamelia patens Jacq. (2803, 2903)

Uncaria guianensis (Aubl.) J. F. Gmel. (R19, PA3, R56, 4015, 4017)

Uncaria tomentosa (Willd.) DC. (PA4)

\section{Scrophulariaceae}

Scoparia dulcis L. (0912)

\section{Solanaceae}

Physalis pubescens L. Ovary pain

(WA5)

\section{Tiliaceae}

Heliocarpus americanus L. (R14)

\section{Urticaceae}

Urera cf. baccifera (R90,

R92)

Urera laciniata Wedd.

(R32, 2817)

\section{Verbenaceae}

Stachytarpheta

cayennensis (Rich.) Vahl

(2805)
Ear pain, caterpillar burn, dysentery, abdominal cramps, post partum care

Swellings, gynaecological disorders, pain in the ovary, rheumatic pain, arthritis, heart pain

Diarrhoea with intestinal cramps and fever

Boils, venomous fish bite, wounds, infection post partum Boils, fever, rheumatism, cold

Threath of miscarriage, fever, malaria, dysentery, burns, herpes, skin infection, disease caused by rainbow spirits

Gynaecological disorder (uterine haemorrhage), internal wounds, rheumatic pain, general fortificant

Gynaecological disorder (uterine haemorrhage), internal wounds, rheumatic pain, general fortificant

Burns, herpes, skin infections, pimples (diseases caused by To prevent hair loss the rainbow spirits); 'susto': miscarriage caused by rainbow spirits, fever, dysenteria

Stomach ache with strong fever, kidney pain, traumas, bruises, swellings, to facilitate birth

Diarrhoea, stomach ache, rheumatic pain, cough, flu

Malaria

Snake bites
Contraceptive, haemorrhage

To strenghten newborn babies, acne

To prevent hair loss, colics, mal aire, kidney-complaints

Diarrhoea

To give birth without pain, to release the placenta after giving birth

Wound healing, high fever, ulcers, mal aire, vaginal infection, sorcery, menstruation pain, cramps, emesis stomach ache, cough, to disinfect wounds, fungal infections

To disinfect wounds, browses and swellings, stomach ache, headache

Osteoarthritis, kidney-complaints, ulcers, liver-complaints, cold, cancer, penis extender,ovary inflammation, prostate, to abort, stomach ache, inflammation

Arthritis, kidney-complaints, stomach ache, inflammation, cold, prostate

Stomach ache, diarrhoea, intestinal parasites

Gastritis, stomach ache, prostate, to give birth rapidly, kidney-complaints, ovary inflammation, inflammation of urinary duct

Mal aire, kidney-complaints, seeing shadows, headache, pain in the muscles after work, general not well being, cramps Sorcery, kidney-complaints, prostate, cramps, Sorcery, mal aire, osteoarthritis, fever, measles, to improve male libido

Snake bites has been reported previously [4,29,69], where ivenkis (Cyperus spp.) for each of the following categories have been indicated: hunting, war, physical illnesses, spiritual illnesses, pregnancy and parturition, children protection, agriculture, handworks, vanity [69]. The Matsigenka cultivate various sedges (Cyperaceae species) with medicinal properties, which they call 'ivenkiki': these are used as hunting medicine and for fertility control [70]. Also the Yanesha cultivate various species of sedges which they call "Piripiri" or "Epe'. Like the Asháninka, they cultivate these plants of high cultural significance around the houses and they use them in a wide array of situations, ranging from behaviour regulation to galactagogue [60]. Plowman et al. [71] reported that the efficacy of the medicinal plants from the genus Cyperus might be related to a rhizome infestation by the ascomycetous fungus Balansia cyperi (Clavicipitaceae) producing ergot alkaloids.

Information on pinitsis is scarce, probably as their use is often related to magical beliefs like love, enchantment and sorcery, which the users might want to keep secret. Pinitsis were also the only plants that the community 
did not permit to be collected and for which the shaman and the midwife requested that secrecy was maintained.

The habit of chewing dried coca leaves together with the bark of 'chamairo' is a custom already reported for the Asháninka living on the Apurimac and Ene rivers of Peru, the Amuesha of the river Pichis and was also reported among other indigenous tribes of eastern Bolivia, who used the crude ash of the spathe or leaf base of the motacú palm (Scheelea princeps (Mart.) Karst.) as an alkaline additive [72].

No specimens were collected in the community for the coca and chamairo plants, as the dried leaves and the stripped bark respectively were normally bought from stalls in Pichanaki. Nevertheless, from the observed reddish colour of the chamairo bark it can be deduced that it was the 'chamairo colorado' or 'red chamairo' identified as Mussatia hyacinthina (Bignoniaceae)[72].

\section{Ailments treated}

The most frequent categories of use of the medicinal plants in the community of Bajo Quimiriki were: dermatological problems, digestive system and cultural belief system. These categories were also reported as the most important in studies carried out among indigenous people in Australia, Fiji, Haiti, India, Kenya, Mexico, Nepal, Nicaragua, North America, Peru, Rotuma, Saudi Arabia, Thailand, Tonga and West Africa [73]. This means that the categories of ailments treated in the community of Bajo Quimiriki with medicinal plants are the same suffered by the majority of rural people in developing countries, while they are different from the ailments categories treated by conventional drugs in developed countries. In the United States, for example, drugs are mainly used against microbial infections, nervous system affections, dermatology and cardiovascular diseases [73].

Problems affecting the skin include among others skin rashes, sunburn, 'arcoiris', 'pokio', hair care, wounds and haemorrhage. This category is also reported as the most important among the Yanesha [60]. Problems related to the digestive system are probably caused by the lack of sewage system and eggs of intestinal parasites present in water or non-washed fruit. Cultural belief system diseases occupy always a big percentage of the medicinal applications in indigenous groups. In the community of Bajo Quimiriki the most mentioned diseases in this category were 'chacho', 'mal aire', 'to bathe babies' and 'sorcery'. Asháninka women bathed their babies in herbal decoctions in order to protect them from illnesses and sorcery, to make them sleep, to calm them, to make them stop crying, to make them obedient, to make them grow healthy and with appetite, to make them sleep, to make them learn to walk fast. This last application indicates the wish of the women who need to go and work in the family chacra to have their children walking as soon as possible. Some of these uses were mentioned also by the Yanesha and reported in Valadeau et al. [60]. Among the diseases most often occurring in the informant's families (Table 6), malaria and 'chacho' were those for which the minor number of medicinal plants was reported. While chacho, a condition provoked by malevolent spirits, is often cured through the intervention of the shaman, malaria is more often cured at home and only in acute cases at the hospital. The scarcity of medicinal plants known to cure malaria might depend from the fact that this disease was introduced into South America from Africa during colonial times, and that therefore indigenous people do not have a long tradition of herbal remedies for it. However, studies in other South American indigenous communities have proven the contrary, reporting numerous species used for this disease $[14,74]$. The explanation could lie in a combination of the following factors: 1) there is a real scarcity of plants for curing malaria in the area, 2) malaria is treated with species that are used against fever, 3) loss of traditional knowledge, 4) preference to be treated in the hospital. All the informants were aware that malaria was transmitted by the bite of infected mosquitoes and mosquito nets were widely used. This is probably due to the fact that this disease and its prevention have been amply publicized by campaigns organized by the Peruvian Ministry of Health, which also distributed free mosquito nets in indigenous communities [75].

In contrast, the parasitic nature of leishmaniasis and the role of sand flies (family Psychodidae) in its transmission were not known by any of the informants and the medicinal plants employed were only applied topically on the visible wounds which are symptoms of the parasitic infection. This has been reported among different ethnic groups in the Loreto and Pasco departments of Peru [14,74]. The Yanesha of the Pasco department use the same spanish names 'uta seca' and 'uta de agua' to indicate the two kinds of leishmaniasis, but differently from the Asháninka of Bajo Quimiriki, they have a myth to explain the disease: an old man called Mareñets who, transformed into a fly, introduces himself into his victim's bodies through a bite and kills them from the inside to steal their spirit [74]. The lack of myths to explain this disease in the community of Bajo Quimiriki does not necessarily indicate acculturation and loss of traditions and believes: the Yanesha myth could also be a reinterpretation in a mythical frame of information from biomedical origin. Only one of the species mentioned against Leishmaniasis was in common with the Yanesha: Jacaranda copaia D.Don (Bignoniaceae). The way of preparation was different: while the Yanesha applied a poultice of boiled leaves on the affected area [74], our informants applied the ashes of the bark on the wounds. Extracts of the leaves of this tree have 
shown some leishmanicidal properties, but the products were found to be toxic for macrophages [76]. It would be interesting to test whether the use of ashes enhances the leishmanicidal activity, while reducing the toxicity previously reported in leaves extracts.

The gender distribution of our adult informants during the household interviews ( 11 women and 5 men) might have influenced our results on number of preserved remedies kept in the house. We registered an alcohol extract of 'Uña de gato' (Uncaria guianensis or Uncaria tomentosa, Rubiaceae) in only one of the 16 visited households. Men were often the ones preparing alcohol extracts in the house and it might be that in their absence their wife did not show these remedies to us.

\section{The shifting role of the traditional healers}

Five people in the community were specialized in different forms of traditional healing. The three men indicated as the 'shaman', the 'curandero', and the 'tobacco healer' were in fact seemingly shamans. In this matter appearances can be deceptive. The "curandero"s discretion is very typical as a really great shaman tends to minimize his powers, unlike the 'official' shaman, who proclaims himself so. And the 'tabaquero' belongs to a former stage of Ashaninka shamanism, before the arrival of Ayahuasca: 'sheripiari' (the Asháninka work for 'shaman') means 'tobacco drinker'. The man who in the community proclaimed himself shaman combined the use of medicinal plants with forms of fortune-telling typically widespread in the cities (cards reading, dice) not common to the community, while the other four specialists used only plants. Fortune-telling is probably to the shaman a way to satisfy the requests of customers coming from cities, a symptom of a shift in shamanism from a traditional practice to a source of income. The demand for services of the local specialists by the city inhabitants could be explained by the fact that many people in Pichanaki have rural origins and trust traditional knowledge. A second reason could be that many people in the city are poor and cannot afford to go to the hospital to give birth or to buy prescribed medicine. This was also mentioned by the local midwife as a reason why she was often called to assist women giving birth in the city.

\section{Knowledge variations}

Traditional medicine was not only in the hands of the specialists: in every household visited some medicinal plants were cultivated or collected from the wild. Common ailments were cured by villagers themselves often using herbal remedies. Men knew plants that were used to treat women ailments and women knew plants used by men. This might be due to the fact that there was not a tradition of keeping dried plant material at home, therefore, when needed men or women would go to collect the herb(s) needed by their spouse or children. An exception was the practice of steam bathing, which seemed to be exclusive dominion of women. This is in accordance with other studies performed among Ashéninka in the Peruvian Amazons [77]. It should be stressed that knowledge was not always transmitted from parents to children. Some informants in their thirties lamented the fact that their parents did not want to teach them what they knew on medicinal plants.

The results of the forest walks indicated that there was a significant correlation between age of the informants and knowledge of medicinal plants. This result has been widely reported $[18,32,78]$ and underlines the vulnerability of traditional plant medicinal knowledge if its transmission through the generations is limited by acculturation or inter-ethnic exchange. Lenaerts [22] reported indeed a loss of the Ashéninka distinctive knowledge among modern Asháninka who were borrowing traditional knowledge from Shipibo neighbours. Nevertheless, in our study the correlation was statistically significant if the whole group of informants was considered, while it was not significant if only the group of women was analyzed. In order to explain the performances of the informants we should consider their personal backgrounds. Flora, the informant aged 71 who had the greatest plant knowledge, was a midwife with a marked personal interest towards medicinal plants. Occasionally she also sold medicinal plants to colonos. Lidia, the exceptionally knowledgeable young female informant (36 years old), was the elder daughter of the local vapour healer and she said to have learnt much from her mother. She explained that when she was very young she wanted to become vaporadora too, but during adolescence she gave up the apprenticeship due to the rigid diet to respect. So, the personal background of this informant explains her particularly profound knowledge compared to her young age. This is also true for one of the main informants with whom the track was established and who provided information on almost all the pre-marked plants. He was 27 years old, brother of the actual leader of the community and son of the local 'curandero'. He said that he was very interested in the use of medicinal plants and that in the future he might have considered becoming a curandero himself. So, although there is a general trend of acquiring medicinal knowledge through the age, much of the variation between informants can be explained by personal interests and also by the relation with a local healer.

The high number of different uses reported for the same species by different informants could be a sign of regional homogenization through borrowing of ethnobotanical knowledge from other ethnic groups or 
neighbouring communities [22] or an indication of an ongoing experimentation with plants properties and lack of communication between the inhabitants who might want to keep their remedies secret to others. In our study the ethnobotanical information on forest plants were collected in a no-random way, using forest walks rather than transects or quadrants. The implications for results were that some of the plants remained unidentified and for some of them we collected ethnobotanical information only from one informant (although we tried to get additional information for 80 plants in the crosscheck).

\section{Knowledge of medicinal plants among the children}

The ethnobotanical information given by the children on 27 medicinal plants was consistent with the information provided by adults on the same plants. The children could not describe the preparation of half of the remedies, probably because at this age they have never actively prepared remedies, but only observed their parents or grandparents getting it ready. In a study on medicinal plant knowledge among mothers and children in Kenya, it was found that school children aged 13-16 participated actively in health care, treating both themselves and their younger siblings with medicinal plants [79]. Maybe this will be the case in the community of Bajo Quimiriki, where after the $6^{\text {th }}$ year of elementary school many of the children will discontinue schooling because their parents cannot afford the school fees.

Twelve out of the twenty-seven plants indicated by the children (44\%) were among the most well-known plants in the community shown in Table 9 and 25 out of 27 plants grew in and around the homegardens. This shows that children's knowledge of medicinal plants is limited to the plants that grow around the households, which probably are used more often than those growing in the forest as they are more accessible. The children did not all have the same knowledge on medicinal plants, some of them were more active in giving names of medicinal plants while some others only confirmed what others had just said. This could be also influenced by shyness, but the oral assessment that we used did not allow us to clearly distinguish these differences. An individual written assessment combined with socio-economic data on the family of origin (Asháninka, colonos or mixed) would better explain how knowledge is transmitted to children.

\section{Comparison with the Yanesha}

We found that 33 of our species (16\% of the plants identified to species) were also used medicinally by the Yanesha. If our plants could have been all identified to species level we might have found more species in common between the two pharmacopoeias. In fact there were also 23 additional plants pertaining to the same genus in common which might have been actually the same species. Our fieldwork of three months in the area limited the possibility of finding fertile voucher specimens and therefore the identification presented some challenges. Nevertheless the fact that in only three months we were able to collect 402 voucher specimens indicates that there is an abundant knowledge and daily use of medicinal plants in this community.

The percentage of species with common uses among the two groups could also be higher if we for example considered that 'liver complaints' could be a symptom of 'malaria' or if we related 'anorexia' with 'stomach infection' and therefore counted them as an identical use. There are many concepts in common between the cosmology of the Yanesha and the Asháninka, like the belief in malignant spirits which reside in the mountains, in the lakes or in the rainbow, wandering souls which can enter ones body and provoke mal aire and the role of the shaman in solving illnesses of this nature. Like in our Asháninka community, also the Yanesha of Oxapampa have different kinds of expert healers where the 'tabaquero' belongs to a former stage of shamanism ('sheripiari', the Asháninka word for 'shaman', means 'tobacco drinker'), while the 'curanderos' which work with Ayahuasca and with other ways of divination are seen with diffidence [60].

\section{Conclusions}

In the community of Bajo Quimiriki, despite the vicinity to the city of Pichanaki, traditional plant knowledge has still a great importance in the daily life: 402 medicinal plants were indicated by the informants for the treatment of 155 different ailments and diseases. Of these, 'mal aire', malaria, diarrhoea, 'chacho', headache and intestinal parasites were reported as the most common among community inhabitants.

The majority of medicinal plants indicated by the informants were herbs, prepared through decoction and administered externally, although shrubs, trees, lianas, epiphytes and arborescent ferns were also indicated. Other traditional ways of preparation included steam baths, always administered by women. The majority of the medicinal plants were found in the forest, followed by the homegardens and along the river. Among the medicinal plants cultivated in the homegardens, two particular categories of plants called pinitsi and ivenki (Cyperus spp.) had an important cultural value, often for magic-protective use in the household.

Exotic plants represented a minor component of the local pharmacopoeia, being limited to 5 species $(2 \%)$. Their uses did not differ from the ones made of local species. 
Medicinal plants knowledge was not restricted to the specialists, but included men, women and also children. There was a significant correlation between age of informants and knowledge of medicinal plants and during the forest walks women could identify more medicinal plants than men. However the differences in knowledge of medicinal plants were also related to personal interest and relation with a local healer. Children could list almost half of the most well-known medicinal plants in the community, but they knew them almost exclusively by their Spanish name. The specialists of the community played a special role dealing with illnesses caused by spirits that inhabited the forest and water or to diagnose the causes of diseases. The shaman and the midwife in the community received mainly non-indigenous customers, showing a progressive shift of their role towards a source of income. The medicinal plants used in this Asháninka community overlapped by $16 \%$ with the medicinal plants reported in three Yanesha communities in the Pasco Region of Peru. The two ethnic groups shared many believes and diseases. This is interesting considering that two of the Yanesha communities were located in remote areas. This fact and the fact that there was a minimum amount of exotic species in the local pharmacopoeia, suggests that despite the vicinity to a city, knowledge on medicinal plants use and traditional believes remain abundant. Moreover the medicinal plants are still available in the surrounding of the community. Documentation and quantification of their actual use could be subjects of future studies. A more accurate study focusing on medicinal plant knowledge in children with data on their family of origin could give a more clear idea of how knowledge is transmitted to the young generations and reveal if this process is threatened. It would be interesting to review the available literature on pharmaceutical properties of the medicinal plants that were most known in the community and of those that were used for similar purposes by the Yanesha. These plants might have a great potential for future drug development.

\section{Additional material}

Additional file 1: Medicinal plants from the Native Community of Bajo Quimiriki. The data provided represent the complete overview on the 402 collected medicinal plants: scientific names, collection numbers, vernacular names, habitat type, life form, use, plant parts used, preparation, route of administration and informants' number, gender and age. The data are provided in the form of a Microsoft Excel spreadsheet.

Additional file 2: List of Asháninka informants. The list provides the names of the inhabitants of the Asháninka Native Community Bajo Quimiriki who participated in the various activities, sharing their knowledge on medicinal plants.

\section{Acknowledgements}

First and foremost we gratefully acknowledge the generous hospitality and assistance provided by all the inhabitants of the Asháninka Native Community of Bajo Quimiriki, in particular the last headman Lino Hereña Quinchocre without whom this work could not have been realized. A complete list of the community members who contributed sharing their knowledge on medicinal plants is given in Additional file 2.

Thanks to Joaquina Albán Castillo, curator of the Herbarium USM in Lima, for use of facilities, application for research permits and identification of voucher specimens. José Dextre Gutierrez, provided invaluable help in the field while collecting, pressing and drying the specimens. Thanks to Roxana Castañeda Sifuentes and Elizabeth Cochachin Guerrero for help in plant identification. A special expression of gratitude goes to Rasmus Sterndorff Hansen, for his assistance during all the fieldwork and his critical comments with anthropological insights.

Also the assistance of Thomas Croat, Axel Dalberg Poulsen and Lars Peter Kvist for identification of voucher specimens was most helpful. This project was funded by the AD grant of the Faculty of Life Sciences (LIFE), Copenhagen University and by the Danish government through DANIDA grant for MSc students. Finally, we thank the Peruvian Government for issuing permission to conduct the study: Authorization No. 086-2007INRENA-IFFS-DCB and export Authorization No. 011447-AG-INRENA.

\section{Author details}

'Department of Agriculture and Ecology, University of Copenhagen, Rolighedsvej 21, DK-1958 Frederiksberg C, Denmark. Forest and Landscape, University of Copenhagen, Rolighedsvej 23, DK-1958 Frederiksberg C, Denmark. ${ }^{3}$ Department of Medicinal Chemistry, University of Copenhagen, Universitetsparken 2, DK-2100 Copenhagen, Denmark.

\section{Authors' contributions}

GL carried out the fieldwork, analyzed the data and drafted the manuscript. MS and IT supervised the work at all its stages, contributing to its conception and design, interpretation of data and drafting of the manuscript. PM gave recommendations to the design of the fieldwork, revised critically the manuscript and provided writing assistance. All authors read and approved the final manuscript.

\section{Competing interests}

The authors declare that they have no competing interests.

Received: 12 December 2009 Accepted: 13 August 2010 Published: 13 August 2010

\section{References}

1. Brack Egg A: Diccionario enciclopédico de plantas útiles del Perú Cusco: Centro de Estudios Regionales andinos "Bartolomé de Las Casas" 1999.

2. Población indígena de la Amazonía peruana supera los 330 mil habitantes. [http://www.inei.gob.pe/web/NotaPrensa/Attach/7999.pdf].

3. WHO Fact Sheet N. 134. [http://www.who.int/mediacentre/factsheets/ fs134/en/print.html].

4. Weiss G: Los Campa Ribereños. Guía Etnográfica de la Alta Amazonia, Campa Ribereños-Ashéninka Smithsonian Tropical Research Institute-Instituto Francés de Estudios AndinosSantos F, Barclay F Lima 2005.

5. Reynel C, Albán J, Léon J, Díaz J: Etnobotanica Campa-Ashaninca con especial referencia a las especies del Bosque Secundario Lima: Universidad Nacional Agraria La Molina, Facultad de Ciencias Forestales 1990.

6. Rojas Zolezzi E: Los Asháninka: un pueblo tras el bosque; Contribución a la etnología de los Campa de la Selva Central Peruana Lima: Pontificia Universidad Católica del Perú 1994.

7. Lamont SR, Eshbaugh WH, Greenberg AM: Species composition, diversity, and use of homegardens among three Amazonian villages. Economic Botany 1999, 53:312-326.

8. Kvist LP: A comparison of qualitative and three quantitative ethnomedicinal methods based on studies in Peru and Ecuador. Uso y Manejo de Recursos Vegetales Memorias del Segundo Simposio Ecuatoriano de Etnobotánica y Botánica Economica Quito: Abya-YalaRíos M, Pedersen HB 1997, 361-382. 
9. Kvist LP, Andersen MK, Hesselsoe M, Vanclay JK: Estimating use-values and relative importance of Amazonian flood plain trees and forests to local inhabitants. Commonwealth Forestry Review 74:293-300.

10. Kvist LP, Oré I, Llapapasca C: Plantas utilizadas en trastornos ginecológicos, parto y control de natalidad en mujeres de la parte baja del río Ucayali - Amazonas peruana. Folia Amazonica 1998, 9:115-141.

11. Kvist LP, Oré I, Gonzales A, Llapapasca C: Estudio de Plantas Medicinales en la Amazonía Peruana: Una Evaluación de Ocho Métodos Etnobotánicos. Folia Amazónica 2001, 12:53-73.

12. Kvist LP, Andersen MK, Stagegaard J, Hesselsøe M, Llapapasca C: Extraction from woody forest plants in flood plain communities in Amazonian Peru: use, choice, evaluation and conservation status of resources. Forest Ecology and Management 2001, 150:147-174.

13. Kvist LP, Gram S, Cácares A, Oré I: Socio-economy of flood plain households in the Peruvian Amazon. Forest Ecology and Management 2001, 150:175-186

14. Kvist LP, Christensen SB, Rasmussen HB, Mejia K, Gonzalez A: Identification and evaluation of Peruvian plants used to treat malaria and leishmaniasis. Journal of Ethnopharmacology 2006, 106:390-402.

15. Padoch C, De Jong W: Diversity, variation, and change in ribereño agriculture. Conservation of neotropical forests New York: Columbia University PressRedford KH, Padoch C 1992, 158-174.

16. Stagegaard J, Sørensen M, Kvist LP: Estimations of the importance of plant resources extracted by inhabitants of Peruvian Amazon flood plains. Perspectives in Plant Ecology Evolution and Systematics 2002, 5:103-122.

17. Phillips O, Gentry AH: The useful plants of Tambopata, Peru: I. Statistical hypotheses tests with a new quantitative technique. Economic Botany 1993, 47:15-32.

18. Phillips O, Gentry AH: The useful plants of Tambopata, Peru: II. Additional hypothesis testing in quantitative ethnobotany. Economic Botany 1993, 47:33-43.

19. Lacaze D, Alexiades M: Salud para todos: plantas medicinales y salud indígena en la cuenca del río Madre de Dios, Perú. Un manual práctico Madre de Dios: Centro de estudios regionales andinos Bartolomé de Las Casas 1995.

20. Sanz-Biset J, Campos-de-la-Cruz J, Epiquién-Rivera MA, Cañigueral S: A first survey on the medicinal plants of the Chazuta valley (Peruvian Amazon). Journal of Ethnopharmacology 2009, 122:333-362.

21. Odonne G, Bourdy G, Castillo D, Estevez Y, Lancha-Tangoa A, AlbanCastillo J, Deharo E, Rojas R, Stien D, Sauvain M: Ta'ta', Huayani: Perception of leishmaniasis and evaluation of medicinal plants used by the Chayahuita in Peru. Part II. Journal of Ethnopharmacology 2009, 126:149-158.

22. Lenaerts M: When Inter-ethnic Botanical Borrowing does not rely on Obvious Efficacy: Some questions from Western Amazonia. Ethnobotany Research and Applications 2006, 4:133-145.

23. Bletter N: A quantitative synthesis of the medicinal ethnobotany of the Malinké of Mali and the Asháninka of Peru, with a new theoretical framework. Journal of Ethnobiology and Ethnomedicine 2007, 3:36.

24. Jovel EM, Cabanillas J, Towers GHN: An ethnobotanical study of the traditional medicine of the Mestizo people of Suni Miraño, Loreto, Peru. Journal of Ethnopharmacology 1996, 53:149-156.

25. Bussmann RW, Sharon D: Traditional medicinal plant use in Northern Peru: tracking two thousand years of healing culture. Journal of Ethnobiology and Ethnomedicine 2006, 2:47.

26. Franquemont C, Plowman T, Franquemont E, King SR, Niezgoda C, Davis W, Sperling CR: The ethnobotany of Chinchero, an Andean community in southern Peru. Book The ethnobotany of Chinchero, an Andean community in southern Peru City: Field Museum of Natural History 1990

27. De-la-Cruz H, Vilcapoma G, Zevallos PA: Ethnobotanical study of medicinal plants used by the Andean people of Canta, Lima, Peru. Journal of Ethnopharmacology 2007, 111:284-294.

28. Keplinger K, Laus G, Wurm M, Dierich MP, Teppner H: Uncaria tomentosa (Willd.) DC.-ethnomedicinal use and new pharmacological, toxicological and botanical results. Journal of Ethnopharmacology 1998, 64:23-34.

29. TSEMIM Transmission et Transformation des Savoirs sur l'Environnement en Milieu Indigène et Métis. [http://www.ulb.ac.be//socio/tsemim/jeuashE. $\mathrm{html}]$
30. Lenaerts M: Substances, relationships and the omnipresence of the body: an overview of Ashéninka ethnomedicine(Western Amazonia). Journal of Ethnobiology and Ethnomedicine 2006, 2:49.

31. Sosnowska J, Balslev H: American palm ethnomedicine: A meta-analysis. Journal of Ethnobiology and Ethnomedicine 2009, 5:43.

32. Shanley P, Rosa NA: Eroding knowledge: An ethnobotanical inventory in eastern Amazonia's logging frontier. Economic Botany 2004, 58:135-160.

33. Case RJ, Pauli GF, Soejarto DD: Factors in maintaining indigenous knowledge among ethnic communities of Manus Island. Economic Botany 2005, 59:356-365.

34. Holdridge LR: Life Zone Ecology San José: Tropical Science Center 1967.

35. INIA Pichanaki Ubicación Geográfica. [http://www.inia.gob.pe/eeas/ pichanaki/ubicacion.htm].

36. Cotton CM: Ethnobotany: principles and applications New York: John Wiley \& Sons 1996.

37. DeWalt SJ, Bourdy G, Chávez de Michel LR, Quenevo C: Ethnobotany of the Tacana: Quantitative Inventories of Two Permanent Plots of Northwestern Bolivia. Economic Botany 1999, 53:237-260

38. Sánchez M, Duivenvoorden JF, Duque A, Miraña P, Cavelier J: A Stembased Ethnobotanical Quantification of Potential Rain Forest Use by Mirañas in NW Amazonia. Ethnobotany Research and Applications 2005, 3:215-229.

39. Thomas E, Vandebroek I, Goetghebeur P, Sanca S, Arrázola S, Van Damme P: The Relationship Between Plant Use and Plant Diversity in the Bolivian Andes, with Special Reference to Medicinal Plant Use. Human Ecology 2008, 36.

40. Ayala Flores F: Taxonomia Vegetal. Gymnospermae y Angiospermae de la Amazonía Peruana lquitos 2003.

41. Vásquez Martínez R, Del Pilar Rojas Gonzáles R: Plantas de la Amazonía Peruana. Clave para identificar las familias de Gymnospermae y Angiospermae Missouri Botanical Garden 2003.

42. Sagástegui Alva A, Leiva González S: Flora Invasora de los Cultivos del Peru Trujillo 1993.

43. Vásquez Martínez R: Flórula de las Reservas Biológicas de lquitos, Perú St. Louis: Missouri Botanical Garden 1997.

44. Ruiz H, Pavón JA: Flora peruviana, et chilensis, sive descriptiones, et icones plantarum peruvianarum, et chilensium, secundum systema linnaeanum digestae, cum characteribus plurium generum evulgatorum reformatis Madrid: Madrid Typis Gabrielis de Sancha1798-1802.

45. Macbride JF, Weberbauer A: Flora of Peru Chicago: Field Museum of Natural History1936-1981.

46. Desmarchelier C, Witting-Schaus F: Sixty Medicinal Plants from the Peruvian Amazon: Ecology, Ethnomedicine and Bioactivity Desmarchelier, WittingSchaus 2000.

47. Castner JL, Timme SL, Duke JA: A Field Guide to Medicinal and Useful Plants of the Upper Amazon Gainesville: Feline Press 1998.

48. Rengifo E, Cerruti T: Plantas Medicinales de la Amazonia Peruana: Estudio de su uso y cultivo lquitos: IIAP 1997.

49. Roth I, Lindorf H: South American medicinal plants: botany, remedial properties and general use Berlin Heidelberg: Springer-Verlag 2002.

50. Gupta MP, (Ed.): 270 Plantas Medicinales Iberoamericanas. Bogota: CYTEDConvenio Andrés Bello 1995.

51. Pennington TD, Reynel C, Daza A: Illustrated guide to the trees of Perú England: David Hunt 2004

52. Mori SA, Cremers G, Gracie C, De Granville J-J, Hoff M, Mitchel JD: Guide to the vascular plants of Central French Guiana. Part 1. Pteridophytes, Gymnosperms, and Monocotyledons New York: The New York Botanical Garden 1997.

53. Duke JA, Vásquez Martínez R: Amazonian Ethnobotanical Dictionary Boca Raton: CRC Press 1994

54. Neotropical Herbarium Specimens. [http://fm1.fieldmuseum.org/vrrc/]

55. Missouri Botanical Garden digital herbarium. [http://mobot.mobot.org/ W3T/Search/image/imagefr.html].

56. Brummitt RK, Powell CE, (Eds.): Authors of plant names. Kew: Royal Botanic Gardens 1992

57. De Lucca M, Zalles AJ: Flora Medicinal Boliviana La Paz: Los Amigos del Libro 1992.

58. Mabberley DJ: Mabberley's Plant-book. A Portable Dictionary of Plants, their Classifications and Uses Cambridge University Press, 32008. 
59. Reynolds GW: The aloes of tropical Africa and Madagascar The Trustees, Aloes Book Fund 1966.

60. Valadeau C, Alban Castillo J, Sauvain M, Francis Lores A, Bourdy G: The rainbow hurts my skin: Medicinal concepts and plant uses among the Yanesha (Amuesha), an Amazonian Peruvian ethnic group. Journal of Ethnopharmacology 2010, 127:175-192.

61. Vásquez Martínez R, Rojas R, Monteagudo AM, Karla MV: Flora vascular de la selva central del Perú: Una aproximación de la composición floristica de tres Areas Naturales Protegidas. ARNALDOA 2005, 12(1-2):112-125.

62. Bussmann RW, Glenn A, Meyer K, Kuhlman A, Townesmith A: Herbal mixtures in traditional medicine in Northern Peru. Journal of Ethnobiology and Ethnomedicine 2010, 6:10.

63. Bussmann RW, Sharon D: Traditional medicinal plant use in Loja province, Southern Ecuador. Journal of Ethnobiology and Ethnomedicine 2006, 2:44.

64. De-la-Cruz H, Vilcapoma G, Zevallos PA: Ethnobotanical study of medicinal plants used by the Andean people of Canta, Lima, Perú. Journal of Ethnopharmacology 2007, 111:284-294.

65. Ssegawa P, Kasenene JM: Medicinal plant diversity and uses in the Sango bay area, Southern Uganda. Journal of Ethnopharmacology 2007, 113:521-540.

66. Sanz-Biset J, Campos-de-la-Cruz J, Epiquién-Rivera MA, Cañigueral S: A first survey on the medicinal plants pf the Chazuta valley (Peruvian Amazon). Journal of Ethnopharmacology 2009, 122:333-362.

67. Tene V, Malagón O, Finzi PV, Vidari G, Armijos C, Zaragoza T: An ethnobotanical survey of medicinal plants used in Loja and ZamoraChinchipe, Ecuador. Journal of Ethnopharmacology 2006, 111:63-81.

68. Coe FG: Rama midwifery in eastern Nicaragua. Journal of Ethnopharmacology 2008, 117:136-157.

69. Anderson RJ: Historias de cambio de los ashéninka Lima: Instituto Lingüístico de Verano 2002

70. Izquierdo C, Shepard GH Jr: Matsigenka. Encyclopedia of Medical Anthropology Springer USEmber CR, Ember M 2004, 2:823-837.

71. Plowman TC, Leuchtmann A, Blaney C, Clay K: Significance of the Fungus Balansia cyperi Infecting Medicinal Species of Cyperus (Cyperaceae) from Amazonia. Economic Botany 1990, 44:452-462.

72. Wade Davis E: The Ethnobotany of Chamairo: Mussatia hyacinthina. Journal of Ethnopharmacology 1983, 9:225-236.

73. Cox PA: The ethnobotanical approach to drug discovery: strenghts and limitations. Ethnobotany and the search for new drugs Chichester: WileyChadwick DJ, Marsh J 1994, 25-41, Novartis Foundation Symposia.

74. Valadeau C, Pabon A, Deharo E, Albán-Castillo J, Estevez Y, Lores FA, Rojas R, Gamboa D, Sauvain M, Castillo D, Bourdy G: Medicinal plants from the Yanesha (Peru): Evaluation of the leishmanicidal and antimalarial activity of selected extracts. Journal of Ethnopharmacology 2009, 123:413-422.

75. Harvey SA, Paredes-Olórtegui M, Leontsini E, Winch PJ: They'll change what they're doing if they know that you're watching: measuring reactivity in health behaviour because of an observer's presence- A case from the Peruvian Amazon. Field Methods 2009, 21:3-25.

76. Chan-Bacab MJ, Peña-Rodriguez LM: Plant natural products with leishmanicidal activity. Natural Product Reports 2001, 18:674-688.

77. Hvalkof $\mathrm{S}$, (Ed.): Dreams coming true...An indigenous health programme in the Peruvian Amazon. Copenhagen: Karen Elise Jensen Foundation and NORDECO 2004

78. Voeks RA: Are women reservoirs of traditional plant knowledge? Gender ethnobotany and globalization in northeast Brazil. Singapore Journal of Tropical Geography 2007, 28:7-20.

79. Geissler PW, Harris SA, Prince RJ, Olsen A, Odhiambo RA, Oketch-Rabah H, Madiega PA, Andersen A, Mølgaard P: Medicinal plants used by Luo mothers and children in Bondo district, Kenya. Journal of Ethnopharmacology 2002, 83:39-54.

\section{doi:10.1186/1746-4269-6-21}

Cite this article as: Luziatelli et al: Asháninka medicinal plants: a case study from the native community of Bajo Quimiriki, Junín, Peru. Journal of Ethnobiology and Ethnomedicine 2010 6:21. 